\title{
37. BENTHIC FORAMINIFERS FROM THE VØRING PLATEAU (ODP LEG 104) ${ }^{1}$
}

\author{
Lisa E. Osterman ${ }^{2}$ and Gunnbjørg Qvale ${ }^{3}$
}

\begin{abstract}
Benthic foraminifers have been studied in about 900 samples from Sites 642, 643, and 644 (ODP Leg 104, Vøring Plateau), ranging in age from Eocene to Holocene. This sequence has been subdivided into seven assemblage zones. The Eocene to middle Miocene deposits are characterized by an agglutinated fauna. This reflects an environment causing dissolution of calcareous tests rather than the original living fauna. The upper Miocene to middle Pliocene deposits contain a diverse benthic foraminiferal fauna dominated by calcareous forms. The uppermost part of the sediment record, deposited during late Pliocene to Holocene, is characterized by many barren intervals and samples containing shallow-water species as well as ice-rafted material indicating glacial periods. Interglacials are reflected in samples containing a true oceanic foraminifer assemblage and no coarse clastic material.
\end{abstract}

\section{INTRODUCTION}

During Leg 104, three sites, 642, 643, and 644, were drilled on the Vøring Plateau (Fig. 1). All three sites were continuously cored, and the sediments recovered ranged in age from Eocene to Holocene. This material represents an excellent basis for detailed studies of benthic foraminifers. Studies of benthic foraminiferal stratigraphy are still in their infancy, especially in subpolar regions where our knowledge is limited. With the study of the Vøring Plateau material we hope to establish a benthic foraminifer stratigraphy from the Eocene to the Holocene, and correlate it with the well-established biostratigraphic zonation based on planktonic organisms. The distribution of benthic foraminifers is controlled mainly by the properties of the bottom-water masses (salinity, temperature, oxygen content), the substrate, and food supply. Therefore the second goal of this study will be to further refine the present knowledge of the paleoceanographic evolution of the Norwegian-Greenland Sea.

The modern surface circulation of the Norwegian-Greenland Sea is dominated by the Norwegian Current (a branch of the North Atlantic surface water), the East Iceland Current and the East Greenland Current (Fig. 1). The Norwegian Current has an important role as a mechanism for transporting heat into the Norwegian Sea, and it is the main source of the North Atlantic deep water (NADW) (Peterson and Rooth, 1976; Worthington, 1970). The Norwegian Current brings warm, saline water into the Norwegian Sea. This water is gradually cooled, sinks to the bottom, and forms the Norwegian Sea deep water. The convective mixing is particularly effective in the area of the oceanic polar front. Part of the deep water flows to the North into the Arctic Ocean forming the polar deep water, and part passes across the Denmark Strait and the Iceland-Faeroe Ridge and contributes to the NADW.

The sediments on the Vøring Plateau were previously drilled during DSDP Leg 38 (Talwani, Udintsev, et al., 1976). Only three sites were continuously cored, Sites 338,339 , and 340 , of which the two latter were located on the flanks of a diapir structure and thus revealed a heavily disturbed sediment sequence, while Site 338 covers sequences comparable to Leg 104 Sites 642

\footnotetext{
${ }^{1}$ Eldholm, O., Thiede, J., Taylor, E., et al., 1989. Proc. ODP, Sci. Results, 104: College Station, TX (Ocean Drilling Program).

2 Department of Geology, The George Washington University, Washington, D.C. 20052 .

3 Norsk Hydro, P.O. Box 200, N-1321 Stabekk, Norway.
}

and 643. Shore-based studies of the Leg 38 sites concentrated only on the agglutinated foraminifers in the lower part of Site 338 (Verdenius and van Hinte, 1983).

\section{METHODS}

For the foraminifer studies, one $20-\mathrm{cm}^{3}$ sample was taken from each of the $1.5-\mathrm{m}$ core sections. The total number of samples added up to about 900 . From most of the samples, about $2 \mathrm{~cm}^{3}$ was removed from each sample for carbonate content analysis (Henrich et al., this volume). The samples were dried at about $70^{\circ} \mathrm{C}$, soaked in lukewarm water of a dilute Calgon (sodium hexametaphosphate) solution to aid disaggregation and then washed over $1.0-$ and $0.063-\mathrm{mm}$ sieves. Some of the hard carbonate samples of Hole $643 \mathrm{~A}$ did not disaggregate by soaking in water or Calgon and had to be treated by further soaking in Varsol. The sand fraction was dried and weighed. The fraction $>1 \mathrm{~mm}$ was usually small and did not contain foraminifers.

The size-fraction $>0.063 \mathrm{~mm}$ was used for the foraminifer studies. In most of the previous DSDP studies the fraction $>0.125$ or even $>0.150 \mathrm{~mm}$ was used. We chose the fraction $>0.063 \mathrm{~mm}$ because a large part of the benthic foraminifer assemblage is lost when using a larger mesh size. This is especially important in our samples, as certain intervals were characterized by small specimens. The same was demonstrated in studies of North Atlantic material (Hermelin and Scott, 1985). The disadvantages of using the small fraction are that numerous juvenile specimens which may be difficult to distinguish will be present in the samples, and that our results will not be directly comparable to previous studies. The latter problem is a definite concern to us, but with densely-spaced samples from a continuous Eocene to Holocene section we wanted to study the total assemblage. We hope that more workers studying foraminifers will adopt the fraction $>0.063 \mathrm{~mm}$ as a standard in micropaleontological analysis.

The sand fraction, or a certain split of this, was spread on a counting tray. Specimens were either picked out and transferred to a separate slide for later studies, or counted directly on the tray. When possible, at least 300 specimens were counted. The number of tube-shaped agglutinated foraminifers in the lower part of Hole 643A may be too high. These forms break easily into smaller pieces while still keeping their original shape. We therefore counted only the larger pieces, but they may still be over-represented.

The percentages of the most important species are presented in Tables 1 through 5 . In samples where the number of specimens was too low to calculate reliable percentages ( $<75$ specimens), the relative percentages are indicated by crosses. The zones established in this study represent assemblage zones. The boundaries have been defined by distinct shifts of the fauna, or by the first/last occurrence of certain species. Each zone is numbered from $\mathrm{A}$ to $\mathrm{E}$ and named after its characteristic species (Fig. 2). The taxonomy used is given in the Appendix.

\section{BENTHIC FORAMINIFER ZONATION}

The foraminifer zonation of each site is shown in Figure 2. These sites form a transect from the inner portion of the Vøring 


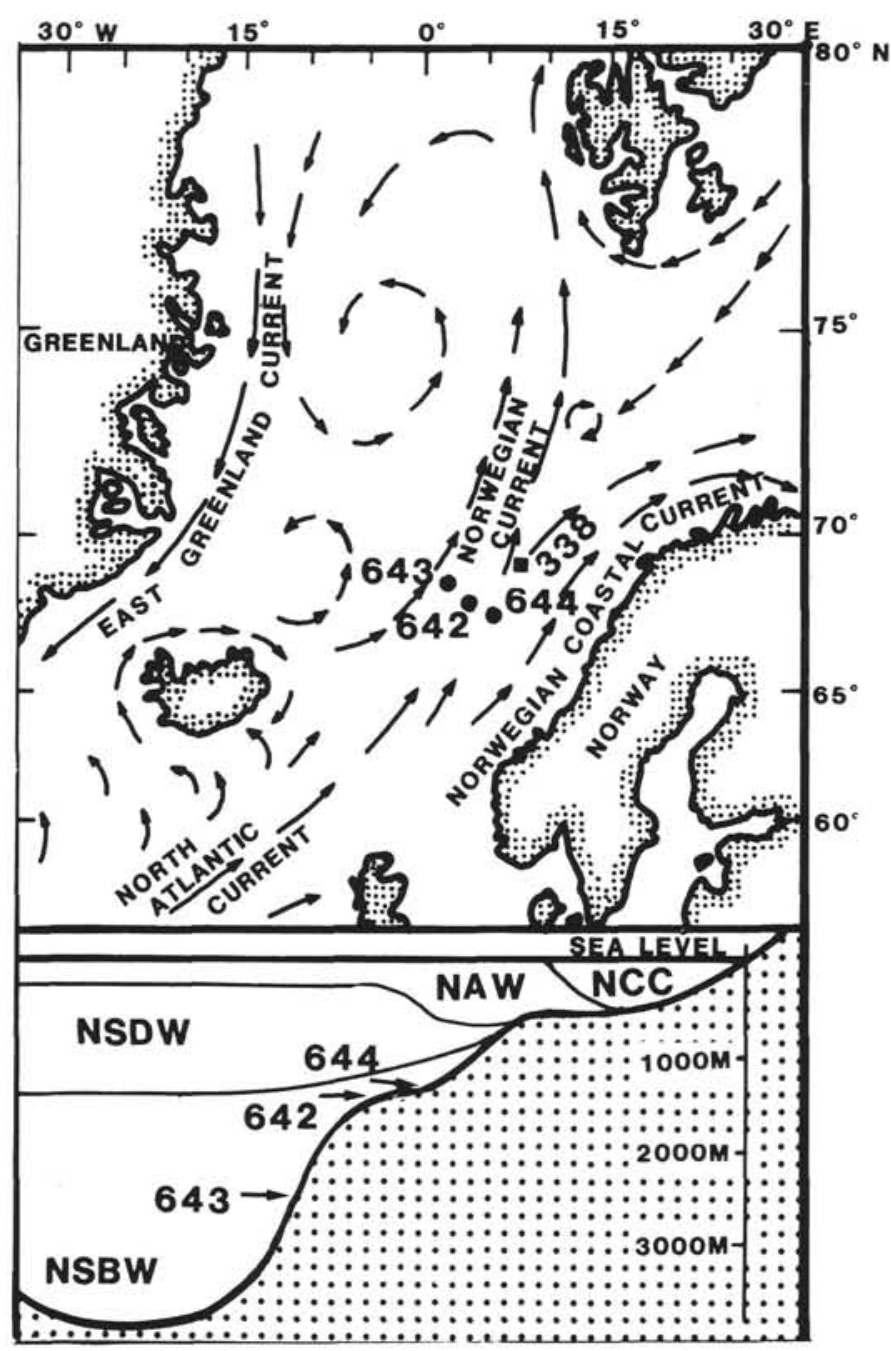

Figure 1. Top: Map of the Norwegian-Greenland Sea showing the locations of Leg 104 Sites 642, 643, and 644 (dark circles) and Leg 38 Site 338 (square) on the Vøring Plateau in relation to the present surface-water currents. Bottom: Cross section of the Vøring Plateau showing the location of the three sites in relation to modern bathymetry and bottomwater masses in the Norwegian Sea. All sites are presently under the influence of the Norwegian Sea bottom water (NSBW). The intermediate water mass is the Norwegian Sea deep water (NSDW), and surface waters consist of the North Atlantic water (NAW) and the Norwegian Coastal Current (NCC).

Plateau (Site 644), to the mid-plateau (Site 642), to the slope of the plateau (Site 643).

\section{Site 644}

The sparse foraminifer fauna of Hole 644A results from the rapid sedimentation rate of this nearshore site $(440 \mathrm{~km}$ from the Norwegian coast). Zone A contains many barren samples which are presumed to be due to high sedimentation rate during glacial intervals. At this site, the benthic foraminifers are divided into Subzones Al and A2 (Table 1). Subzone A1 from 0 to $206 \mathrm{mbsf}$ (Sample 104-644A-24H-4, 75-79 cm) is characterized by the presence of Cassidulina laevigata as well as numerous reworked shallow-water foraminifers including Elphidium excavatum. Subzones A1 and A2 are separated by a barren interval from 206 to 239 mbsf. Subzone A2 from 239 mbsf (Sample 104-644A$32 \mathrm{H}-1,75-79 \mathrm{~cm})$ to the base of the hole also contains Cassidulina laevigata.

\section{Site 642}

Site 642 (Holes 642B, 642C and 642D) contains a longer record, extending back to Eocene (Smalley et al., and Manum et al., this volume; Goll, this volume). Foraminifers are present only in the Neogene and Quaternary sequence, and three assemblage zones have been defined. Although benthic foraminifer counts have been made on all three holes (Tables 2, 3, and 4), for simplicity this discussion will refer only to Hole 642B depths. The earliest foraminifer fauna present in Hole 642B is a rather sparse, exclusively agglutinated assemblage including Spirosigmoilinella spp. and Spirolocammina sp. which comprise Subzone C2 from Sample 104- 642B-23H-1, 66-69cm (197 mbsf) to the base of the hole (Table 2). In Subzone C1 (197 to 163 mbsf in Hole 642B), Martinottiella communis is also present and occurs in rare numbers well into Zone B.

In Core 104-642B-19H (163 mbsf) there is a faunal change to a dominantly calcareous foraminifer assemblage synchronous with an unconformity. Zone B (129 to 163 mbsf in Hole 642B) contains a moderately diverse and abundant benthic foraminifer assemblage including Epistominella exigua and several Cibicides and Uvigerina species, especially U. pygmaea. Because of the continued presence of the rare agglutinated species in this zone, it is possible that this faunal change represents a change in oceanic chemistry and increased carbonate preservation instead of a true faunal shift. The unconformable nature of the boundary between agglutinated and calcareous faunas suggests an oceanographic change with resulting erosion.

Subzones A1 and A2 of Site 642 are very similar in faunal composition to that of Hole $644 \mathrm{~A}$, but at Site 642 the abbreviated sequence is due to the decreased sedimentation rates. Subzone A2 (129 to 67 mbsf) in Hole 642B includes Melonis zaandami, Epistominella exigua, and Cassidulina subglobosa, as well as the first appearance of $C$. laevigata at 113 mbsf (Sample 104-642B-13H-6, 74-78 cm) Subzone A1 (0 to $39 \mathrm{mbsf}$ ) includes C. laevigata, Oridorsalis umbonatus, Cassidulina reniforme, and some reworked shallow-water Elphidium spp. The two subzones are separated by a barren interval ( 39 to $129 \mathrm{mbsf}$ ) in both Hole $642 B$ and $642 C$.

\section{Site 643}

The benthic foraminifer record of Site 643 is separated from the basement basalts by a barren interval from 545 mbsf to the base of this hole. The oldest foraminifers found in Zone E (503 to $545 \mathrm{mbsf}$ ) consist of a diverse group of agglutinated foraminifers dominated by the Rhabdammina and Rhizammina types, but includes a few Cyclammina spp, suggesting a post-Paleocene age (Table 5). Zone D (332 to $503 \mathrm{mbsf}$ ) includes many of the same agglutinated species found in Zone E but is generally lacking the large number of tube-shaped foraminifers and is characterized by Haplophragmoides walteri and numerous $\mathrm{Cy}$ clammina spp. The agglutinated foraminifers continue into Zone C2 ( 97 to $332 \mathrm{mbsf}$ ), which is characterized by rare specimens of Spirosigmoilinella spp.. Zone C1, found at Site 642 (Martinottiella communis) is missing at Site 643.

At $97 \mathrm{mbsf}$ in Hole 643A there is a shift to the abundant calcareous fauna of Zone B which occurs from 69 to $97 \mathrm{mbsf}$. Zone B is characterized by Cibicides spp. and Uvigerina spp., especially $U$. pygmaea. Zone A (0-69 mbsf) is characterized by the presence of ice-rafted sediment and a benthic foraminifer fauna including Stetsonia horvathi, Pyrgo murrhina, and Cibicides wuellerstorfi, as well as an intermediate barren zone similar to the other two sites. The rationale for use of the fraction $>0.063 \mathrm{~mm}$ is seen most convincingly in Zones A and B of Sites 642 and 643 . In these zones small-sized foraminifers, including Epistominella exigua and Stetsonia horvathi, dominate many of the samples, and would be missed if a larger sized sieve were used. 
Table 1. Percent of selected benthic foraminifer species* in Hole 644A.

\begin{tabular}{|c|c|c|c|c|c|c|c|c|c|c|c|c|c|}
\hline Sample $(\mathrm{cm})$ & C. laevig & C. renif & M. zaand & E. excav & B. acule & B. margin & E. umbo & E. exigua & C. wuell & Other & $\% \mathrm{BF}$ & No. $/ \mathrm{cm}^{3}$ & Zones \\
\hline $1-1,75-79$ & & & & & & & & & & * & 100 & 0.05 & \\
\hline $1-3,75-79$ & 61.7 & 4.4 & 8.8 & 11.8 & & & & & 1.5 & 8.8 & 5.7 & 7.6 & \\
\hline $1-5,75-79$ & 41.2 & 0.6 & 49.7 & 1.2 & & & 3.6 & & & 3.6 & 17.2 & 10.3 & \\
\hline $1, \mathrm{CC}, 13-17$ & 50.7 & 3 & 1.7 & 44.8 & & & & & & 0.7 & 26.2 & 33.1 & \\
\hline $2-2,74-77$ & 40.9 & & & 0.3 & & & 0.7 & & 43.2 & 1.3 & 2.1 & 4.9 & \\
\hline $2-4,74-77$ & ++ & & & * & & & • & & & 0 & 5.3 & 1.8 & \\
\hline $3-1,75-79$ & $*$ & & & & & & & & & 0 & 0.01 & 0.1 & \\
\hline $3-3,75-79$ & 77.5 & 12.7 & 1 & 6.4 & & & 0.5 & & & 2 & 4.8 & 45.3 & \\
\hline $3-5,75-79$ & * & & & & & & & & & 0 & 0.01 & 0.1 & \\
\hline $4-1,74-78$ & 63.3 & 0.5 & & 0.5 & & & 1.9 & & & 1.5 & 32.5 & 57.5 & \\
\hline $4-3,74-78$ & 4.4 & & & & 35.8 & 35.8 & & & & 23.8 & 15.2 & 14.9 & \\
\hline $4-5,74-78$ & 72.6 & & 4.9 & 16.4 & 1.3 & 1.8 & 0.9 & & & 2.2 & 55.7 & 125.6 & \\
\hline $4, C C, 19-23$ & 17.6 & 1.8 & 19.4 & & 0.6 & & & & 0.6 & 5.5 & 27.1 & 9.2 & \\
\hline $5-2,75-78$ & & & & * & & & & & & - & 0.01 & 0.1 & \\
\hline $5-4,75-78$ & 76.2 & 10.2 & 6.4 & 1.3 & & & & & & 6 & 45.8 & 65.3 & \\
\hline $5, C C, 12-16$ & 38.4 & 3.9 & 0.3 & 57 & & & & & & 0.3 & 42.9 & 155 & \\
\hline $6-2,80-84$ & • & & & * & & & & & & 0 & 0.01 & 0.39 & \\
\hline $6-4,80-84$ & 76 & 16.5 & 0.7 & & & 0.7 & 0.7 & & & 2.5 & 10.2 & 1116 & \\
\hline $6-6,80-84$ & 79.4 & 11.3 & 3.8 & 1.3 & & & 1 & 2.1 & & 1 & 34.4 & 582 & \\
\hline $7-1,75-80$ & & Barren & & & & & & & & & & & \\
\hline $7-3,75-80$ & 0.3 & & & 93.4 & & & & & & 0.3 & 38.3 & 161 & \\
\hline 7, CC, 37-41 & 41.9 & 2.6 & & 54.6 & & & & & & 0.9 & 61.1 & 63 & \\
\hline $\begin{array}{l}8-2,76-80 \\
8-5,76-80\end{array}$ & 27.5 & $\begin{array}{c}4.4 \\
\text { Barren }\end{array}$ & 1.8 & 17.9 & 33.6 & & & 5.2 & & 9.6 & 25.4 & 25.4 & \\
\hline $\begin{array}{l}8-5,76-80 \\
8, C C, 18-22\end{array}$ & 35 & 12.2 & 36.5 & 1 & & & & 6.1 & 1.3 & 2.9 & 7.8 & 210.7 & \\
\hline $9-2,73-77$ & +++ & $*$ & & + & & & & & & +++ & 10.5 & 3.3 & \\
\hline $9-4,73-77$ & 59.1 & 6.5 & 8.4 & & & & 0.6 & 16.9 & & 8.4 & 35.7 & 8.6 & \\
\hline $9, \mathrm{CC}, 17-21$ & +++ & + & + & + & & & $*$ & & & + & 11 & 3.2 & \\
\hline $10-2,92-95$ & 27.7 & 52 & 1.1 & & & & & 0.4 & 14.5 & 4.3 & 6.8 & 130.3 & \\
\hline $10-4,92-95$ & & & & & & & & & & $\cdot$ & 0.01 & 0.05 & \\
\hline $10, \mathrm{CC}, 20-23$ & * & & & • & & + & & & & ++ & 24.2 & 3.8 & \\
\hline $11-2,75-79$ & 40.7 & 4.4 & 51.6 & & & & & & & 3.3 & 29.7 & 5.1 & \\
\hline $11-4,75-79$ & 12.4 & 1.4 & 2.5 & 1 & & & & 35.5 & & 47.2 & 36.9 & 141 & \\
\hline $11-5,79-83$ & 37.1 & 2.2 & 34.1 & & & & & 22.4 & & 4.3 & 91.3 & 12.9 & \\
\hline $11, \mathrm{CC}, 6-10$ & 66.6 & 18.9 & 4.2 & & & & & 1.6 & & 8.7 & 34.5 & 105.6 & \\
\hline $12-2,75-79$ & $*$ & & & & & & & & & 0 & 0.01 & 0.05 & A) \\
\hline $12-4,75-79$ & 87.2 & 9.2 & 2.5 & & & & & & & 1.2 & 58 & 288.5 & A1 \\
\hline $12-6,70-72$ & 79.2 & 9.1 & 6.1 & & & & & & & 5.5 & 19.8 & 82.5 & \\
\hline $12-6,75-79$ & 79.2 & 9.1 & 6.1 & & & & & & & 5.5 & 19.8 & 82.5 & \\
\hline $13-2,73-77$ & ++ & & + & & & & & & & 0 & 48.8 & 1.3 & \\
\hline $13-5,73-77$ & + & & $*$ & + & ++ & ++ & & & & $*$ & 90 & 8.5 & \\
\hline $13-7,73-77$ & 79.9 & 6.9 & 5.6 & & & & & 0.7 & & 0.7 & 27.4 & 9 & \\
\hline $14-1,88-92$ & 71.5 & 2 & 12.7 & & & & & 4.9 & & 8.8 & 91.1 & 6 & \\
\hline $14-3,88-92$ & + & & + & & & & & + & & + & 100 & 0.8 & \\
\hline $14-5,88-92$ & 25.7 & 0.3 & 7.3 & & & & & 61.7 & & 5 & 99.7 & 285 & \\
\hline $15-1,74-78$ & 63.8 & 0.5 & 29.8 & & & & & 1.8 & & 4.1 & 94.4 & 12.1 & \\
\hline $15-3,74-78$ & 32.6 & 1.2 & 4.5 & & & & & 57.5 & & 4.2 & 87.9 & 278.3 & \\
\hline $15-5,74-78$ & 30.8 & 0.5 & 15.1 & & & & & 46.7 & & 6.9 & 82.6 & 195 & \\
\hline $15-7,74-78$ & * & & & & & & & & & 0 & 50 & 0.05 & \\
\hline $16-1,75-79$ & 30.4 & & 9.1 & & & & & 55.5 & 1.7 & 3.3 & 64.9 & 348.3 & \\
\hline $16-3,75-79$ & 40.2 & & 39.2 & & & & & 18.6 & & 2 & 92.7 & 34 & \\
\hline $16-5,75-79$ & $*$ & & & & & & & & & 0 & 67 & 0.11 & \\
\hline $17-4,75-79$ & 54.4 & & 20.2 & & & & & 19.9 & & 5.5 & 16.7 & 68 & \\
\hline $17, C C, 15-19$ & 32.4 & & 56.3 & & & & 0.6 & 8.7 & & 2.1 & 99.4 & 29.3 & \\
\hline $18-2,75-79$ & & & & & & & & & & * & 100 & 0.17 & \\
\hline $18-4,75-79$ & 48.3 & & 21.3 & & & & & 28.4 & & 1.9 & 96.3 & 11.7 & \\
\hline $18-6,75-79$ & 20.2 & & 29 & & & & & 49.9 & & 1 & 99.1 & 46.8 & \\
\hline $19-2,74-78$ & & Barren & & & & & & & & & & & \\
\hline $19-3,74-78$ & 49.2 & & 16.6 & & & & & 36.5 & & 3.6 & 99.3 & 33.4 & \\
\hline $19, \mathrm{CC}, 11-13$ & 51.5 & & 22.2 & & & & & 23.8 & & 2.5 & 73.5 & 40.5 & \\
\hline $20-1,74-78$ & 26 & & 14.2 & & & & & 59.1 & & 0.7 & 99.3 & 65.8 & \\
\hline $20-3,74-78$ & 30 & & 33.3 & & & & & 35.5 & & 1.1 & 87.8 & 60.7 & \\
\hline $20-5,74-78$ & 24.7 & & 11.7 & & & & & 63.2 & & 0.4 & 95.3 & 49.6 & \\
\hline $21, \mathrm{CC}, 15-19$ & 83.3 & & 4.3 & & & & & 12.3 & & 0 & 99.3 & 7.7 & \\
\hline $22-2,75-79$ & 93.5 & & & & & & & 6.5 & & 0 & 98.4 & 13.8 & \\
\hline $22-4,75-79$ & 10.3 & & 5.9 & & & & & 83.1 & & 0.7 & 43.9 & 153 & \\
\hline $22, \mathrm{CC}, 10-14$ & 43.6 & 1.2 & 32.8 & & & & & 15.5 & & 6.9 & 67.6 & 18.6 & \\
\hline $23-3,72-76$ & + & & & & & & & & & 0 & 91 & 0.5 & \\
\hline $23-5,72-76$ & 49.7 & 2.1 & 2.8 & & & & & 33.1 & & 6.9 & 90.6 & 8.1 & \\
\hline $24-1,75-79$ & & Barren & & & & & & & & & & & \\
\hline $24-3,75-79$ & 30.9 & & 0.7 & & & & & 66.3 & & 2.1 & 98.6 & 15.7 & \\
\hline $25-2,75-79$ & & Barren & & & & & & & & & & & \\
\hline $25, \mathrm{CC}, 10-14$ & & Barren & & & & & & & & & & & \\
\hline $26-2,89-93$ & & Barren & & & & & & & & & & & \\
\hline $26, C C, 15-19$ & ++ & & & & & & & & & * & 18.2 & 0.8 & \\
\hline $27, \mathrm{CC}, 14-18$ & & Barren & & & & & & & & & & & \\
\hline $28-2,73-77$ & +++ & & & & & & & * & & ++ & 76 & 4 & Barren \\
\hline $28, C C, 20-24$ & & Barren & & & & & & & & & & & Barten \\
\hline $29-2,75-79$ & ++ & & * & & & & & ++ & & + & 89.7 & 3.4 & \\
\hline $29, \mathrm{CC}, 20-24$ & & Barren & & & & & & & & & & & \\
\hline $30-2,75-79$ & & Barren & & & & & & & & & & & \\
\hline $30-4,75-79$ & & Barren & & & & & & & & & & & \\
\hline $32-1,75-79$ & & Barren & & & & & & & & & & & \\
\hline
\end{tabular}


Table 1 (continued).

\begin{tabular}{|c|c|c|c|c|c|c|c|c|c|c|c|c|c|}
\hline Sample $(\mathrm{cm})$ & C. laevig & C. renif & M. zaand & E. excav & B. acule & B. margin & E. umbo & E. exigua & C. wuell & Other & $\% \mathrm{BF}$ & No. $/ \mathrm{cm}^{3}$ & Zones \\
\hline $32-3,75-79$ & 45.6 & 6.4 & 6.9 & & & & & 13.1 & & 27.9 & 58.2 & 22.9 & \\
\hline $32, \mathrm{CC}, 4-8$ & 52.8 & 1.4 & 4.1 & & & & & 7.8 & & 24.8 & 84.1 & 12.1 & \\
\hline $33, \mathrm{CC}, 10-14$ & 33.3 & 2.6 & 3.8 & & & & & 28.2 & & 32 & 100 & 4.3 & \\
\hline $34-2,75-79$ & + & & & & & & & & & - & 100 & 0.3 & $\mathrm{~A} 2$ \\
\hline $34-5,75-79$ & 61.7 & 4 & & & & & & 5.5 & & 28.9 & 79.3 & 11.8 & \\
\hline 34, CC, $18-22$ & 24.4 & 1.1 & 4.4 & & & & & 7 & & 63.1 & 48.1 & 135.5 & \\
\hline
\end{tabular}

-Species: $C$. laevig = Cassidulina laevigata C. renif $=$ Cassidulina reniforme,$M$. zaand $=$ Melonis zaandami; $E$. excav $=$ Elphidium excavatum; $B$. acule $=$ Bulimina aculeata $; B$. margin = Bulimina marginata $;$. umbo $=$ Oridorsalis umbonatus; $E$. exigua $=$ Epistominella exigua $;$. wuell $=$ Cibicides wuellerstorfi.

\section{DISCUSSION}

The benthic foraminifer fauna of Leg 104 is similar to that of other North Atlantic and North Sea drill sites (Murray, 1984, 1987; Berggren and Schnitker, 1983; Miller et al., 1982; King, 1983; Gradstein and Berggren, 1981). The agglutinated bathyal foraminifers of Zones E and D (Site 643) including Haplophragmoides spp., Cyclammina spp., Ammodiscus spp., and Bathysiphon, have been termed a flysch assemblage and have been recorded from numerous areas worldwide (Gradstein and Berggren, 1981; Miller et al., 1982; Kaminski et al., 1988). This agglutinated assemblage, called the Type $A$ agglutinated assemblage by Miller et al. (1982), consists of large, coarsely agglutinated simple forms like Rhabdammina. The Type A assemblage is found in slope basins and rapidly subsiding troughs with restricted bottom-water circulation and rapid sedimentation, which limits normal calcareous fauna by favoring development and preservation of agglutinated foraminifers. The paleodepths of the Type A assemblage, as reported by Miller et al. (1982), is on the order of 2.5 to $4.5 \mathrm{~km}$, however depth alone is not the controlling factor of its distribution. The flysch assemblage disappeared from the North Sea during the late Eocene to early Oligocene (Gradstein and Berggren, 1981), but appears to have lasted longer in the Norwegian Sea (Miller et al., 1982). In fact, Miller et al. (1982) suggested that the agglutinated assemblage, as reported in the Leg 38 shipboard report (Talwani, Udintsev, et al., 1976), may be taxonomically distinct from their Type A assemblage. Currently, we do not recognize much difference between the Type A assemblage of Miller et al. (1982) and the agglutinated fauna of our Zones D and E, but this statement is based only on our qualitative analysis of the fauna. Further identification of this difficult assemblage still remains to be done.

However, the important question for this discussion is whether the Vøring Plateau fauna is indicative of an environment similar to other Type A assemblages or just characteristic of the upper Eocene bathyal assemblage of the Norwegian-Greenland Sea as Verdenius and van Hinte (1983) suggested. Two lines of evidence suggest that the lower portion of Site 643 represents a time of rapid sedimentation, with influx of continent- or shelf-derived material. First, the sediments deposited during this interval consist of laminated mudstones (Eldholm, Thiede, Taylor, et al., 1987). Second is the rare occurrence of shallow-water calcareous foraminifers such as Ammonia beccarii and Elphidium sp. in Zone D, which suggest downslope transport (Samples: 104-643A$38 \mathrm{X}-2$, 76-79 cm, 354 mbsf; 104-643A-42X-6, 66-70 cm, 396 mbsf; and 104-643A-46X-6, 75-78 cm, $434 \mathrm{mbsf}$ ).

The presence of abundant Spiroplectammina spectabilis in Zone $\mathrm{E}$ and the lower portion of Zone D (Cores 104-643A-59X through 104-643A-47X, 555 to $449 \mathrm{mbsf}$ ) can be used to date these deposits. This species is found in sediments ranging in age from the Campanian through the Eocene of the North Atlantic Basin. King (1983) reported that it is characteristic of the upper
Eocene in the North Sea, and is reported in same interval in the Norwegian-Greenland Sea (Verdenius and van Hinte, 1983), while its upper limit is the middle Eocene in the Labrador Sea (Gradstein and Berggren, 1981). The similarity of the fauna from the Vøring Plateau and the North Sea Basin strongly suggests that a deep-water connection existed between these basins during the Eocene. Calcareous foraminifera are extremely rare in the lower part of Hole $643 \mathrm{~A}$, but one sample can provide another age for Zone D. Sample 104-643A-43X-CC (410 mbsf) contains calcareous foraminifers including Turrilina alsatica and Anomalinoides alazanensis which indicates that this interval was deposited during the Oligocene. These calcareous assemblages are similar to Oligocene faunas of Site 348 of the Iceland-Faeroe Ridge (Talwani, Udintsev, et al., 1976) and in Europe (King, 1983).

The agglutinated benthic foraminiferal assemblage of Zone $\mathrm{C}$ is restricted mainly to the North Sea Basin and Norwegian Sea (Talwani, Udintsev, et al., 1976; Gradstein and Berggren, 1981; King, 1983; and Verdenius and van Hinte, 1983). Gradstein and Berggren (1981) recognized the foraminifer Rzehakina sp. 1 from the North Sea, which they reported as coeval with the upper range of $C$. amplectens (Eocene) in the North Sea and ranging into the lower to middle Miocene. Verdenius and van Hinte (1983) placed Spirosigmoilinella sp. in synonymy with Rzehakina sp. 1 of Gradstein and Berggren (1981). The most likely age for Zone $\mathrm{C}$ sediments ranges from the lower Miocene and lasting through the middle Miocene (Goll, this volume).

Calcareous foraminifers are exceedingly rare in Zone $\mathrm{C}$, and the dominant fauna consists primarily of the agglutinated genera Spirolocammina and Spirosigmoilinella. Verdenius and van Hinte (1983) defined these genera as matrix-walled, which indicates an absence of sand-sized particles during this interval. This is also reflected in the sediment type, which changes from the continent-derived sediments (lithological Unit IV) to siliceous muds and oozes (lithological Unit III) near the base of Zone C (Eldholm, Thiede, Taylor, et al., 1987). Verdenius and van Hinte (1983) estimated the sedimentation rate for this siliceous interval at Site 338 to be $0.5 \mathrm{~cm} / 1000 \mathrm{yr}$, three times slower than the underlying Oligocene clastics. They concluded that because of the reduced fauna, but increased time interval of the siliceous sedimentation, the sea bottom during the Miocene was a harsh, low-nutrient environment with little food supply, resulting in the meager fauna.

However, other evidence suggests that the low-nutrient environment envisioned by Verdenius and van Hinte (1983) may not have been the case. Evidence of rising rates of biogenic silica in Hole 643A from 274 to 100 mbsf suggests high fertility and upwelling. The large amount of biogenic silica in many samples of Zone $\mathrm{C}$ suggests that great biological productivity occurred at that time. It is also possible that the volcanic ash deposits of the Norwegian Sea could have provided the necessary silica for the biological blooms as suggested by Berggren and Schnitker (1983). Contrary to the suggestion by Verdenius and van Hinte (1983), 
we believe that the deposition of siliceous plankton would have provided an abundant food supply, but the decay of such organisms on the sea floor would cause a lowering of the $\mathrm{pH}$, resulting in hampered calcite precipitation or increased dissolution of calcareous tests. Small numbers of calcareous foraminifers $(\mathrm{Ci}-$ bicides spp. and Uvigerina pygmaea) and Miocene Bolboforma are found to the depth of Sample 104-643A-29X-CC, 11-15 cm (263 mbsf) in Zone C2 of Hole 643A, and 104-6428-22H-6, 70$73 \mathrm{~cm}$ (193 mbsf) in Zone $\mathrm{C} 1$ of Hole 6428 . This indicates to us that the absence of calcareous foraminifers in Zone C is mainly due to dissolution and not to a low-nutrient environment.

The appearance of abundant calcareous foraminifers at both Sites 642 and 643 is within several meters of the first appearance of calcareous and nannofossil oozes on the Vøring Plateau (Samples 104-642B-19H-4, 72-76 cm, 163 mbsf and 104-643A, $11 \mathrm{H}-5,75-79,97 \mathrm{mbsf})$. The change in sediment type associated with the introduction of rich calcareous faunas, the rare occurrence of calcareous foraminifers in Zone $C$ and the continued occurrence of agglutinated species through Zone B suggest that the agglutinated fauna of Zone $\mathrm{C}$ is a result of extreme calcium carbonate dissolution during the early to middle Miocene.

A similar faunal association to Zone C of the Vøring Plateau was also reported in the Labrador Sea (Gradstein and Berggren, 1981). Above the Labrador Sea Type $A$ flysch assemblage (comparable to Zones D and E), a sparse agglutinated fauna with Cyclammina sp. and Ammodiscus sp. is found until the lower Miocene. In association with this sparse agglutinated fauna are calcareous benthics that also show evidence of dissolution. Gradstein and Berggren (1981) believe that this dissolution is a postdepositional alteration of the fauna. We would also have to consider that the lack of calcareous foraminifers in Zone $\mathrm{C}$ could represent thanatocoenosis, at the time of deposition as well as at a later time.

Another question that needs to be addressed is the difference in the composition of Zone $C$ between Sites 642 and 643. At Site 642 , Zone C is composed of two subzones; Subzone C1, characterized by Martinottiella communis, and Subzone C2, characterized by Spirosigmoilinella spp. At Site 643 the absence of $M$. communis suggests that this species is restricted to shallower water, or that part of Subzone C1 is missing at Site 643.

The change from the agglutinated fauna of Zone $C$ to the calcareous fauna of Zone B is a pronounced one that is associated with a change in sediment type as mentioned above, and an unconformity at both Sites 642 and 643 . The calcareous fauna of Zone B represents a transition from the benthic foraminifers of the early Miocene to the modern species which were becoming established at that time. Holdover genera include Uvigerina and the various Cibicides species, which are found sporadically from 104-643A-29X-CC, 11-15 (263 mbsf) and 104-642B-22H$6,70-73 \mathrm{~cm}$ (193 mbsf). Modern genera originating at that time include Epistominella exigua and Cassidulina. Zone B lasted only a short time after the calcium carbonate compensation depth (CCD) was lowered in the Norwegian Sea. The sequence is about $30 \mathrm{~m}$ at each site, representing a period of less than two million yr.

Many of the samples from the uppermost $50 \mathrm{~m}$ of sediment at all three sites are barren, or contain a very poor assemblage. This interval comprises assemblage Zone A. The sediments are dominated by glacial muds with abundant ice-rafted material. An exciting result of this research is the recognition of Stetsonia horvathi in the upper Quaternary section of Site 643. This benthic foraminifer was previously unrecognized in the Norwegian Sea (Belanger and Streeter, 1980), but has been observed in the modern Arctic Ocean (Lagoe, 1977). The main difference in these two studies was the use of the $0.063-\mathrm{mm}$ sieve fraction by Lagoe (1977). While the use of the smaller sized sieve in our study has the main disadvantage of correlation with other stud- ies, the information acquired by the use of the smaller sieve is more than justified.

\section{PALEOCEANOGRAPHY}

The oldest sediments recovered at Site 643 indicate a bathyal environment on the Vøring Plateau with oceanic connections to the Labrador Sea, the North Atlantic, and the North Sea (Gradstein and Berggren, 1981; Miller et al., 1982; Murray, 1987). These sediments, which include benthic foraminifer Zone E with $S$. spectabilis, are believed to date to the Eocene; palynomorph data suggest a date of early to middle Eocene (Manum et al., this volume). Throughout that time the sedimentation consisted of terrigenously derived laminated mudstones, deposited as turbidites adjacent to the newly spreading ridge. The characteristic agglutinated flysch assemblage indicates that this area was below the CCD. Thin carbonate-rich layers occur occasionally in Cores 104-643A-40X through 104-643A-52X (371 to 497 mbsf). In the lower part of Core 104-643A-42 (396 mbsf), lamina of nannofossil ooze were observed. In the calcareous layers, perhaps buffered from dissolution, calcareous foraminifers were observed. These included some transported, long-ranging taxa such as Elphidium and Ammonia, in addition to deeper water forms. The agglutinated foraminifer assemblage found during the Eocene is comparable to the Labrador Sea and North Sea, indicating water exchange between these basins and the Norwegian Sea. This is in agreement with Miller and Tucholke (1983), who believe that there was surface-water connection between the Norwegian Sea and the North Atlantic since the early Eocene. Our research strengthens the argument for deep-water exchange as well.

Late Eocene to early Oligocene cooling of the world's oceans is manifested in the North Atlantic by impoverished planktonic floras and faunas as well as dramatic deep-water foraminifer changes (Berggren and Schnitker, 1983). Cooling resulted in the extinction and the origination of species and the depth adjustments of others. During the same time there was a global deepening of the CCD and intensification of the deep currents resulting in widespread unconformities (Berggren and Schnitker, 1983). These unconformities have been used as evidence for the initiation of North Atlantic bottom waters at that time (Miller and Tucholke, 1983). However, this is in conflict with other research which supports the idea that bottom water did not form until mid Miocene (Schnitker, 1980). Due to the meager foraminifer fauna through this interval, the question of when the Norwegian-Greenland Sea became a source of bottom water in the North Atlantic is not likely to be answered by this study.

Although it appears as though a surface- and deep-water connection between the North Atlantic and the Norwegian Sea may have existed from the early Eocene (Miller and Tucholke, 1983; this study), it is uncertain when the initiation of North Atlantic surface water (NASW) began. Evidence for surfacewater exchange comes from the previously reported middle to upper Oligocene calcareous oozes on the Vøring Plateau (Talwani, Udintsev, et al., 1976). The deposition of calcareous oozes indicates that water was entering the Norwegian Sea during the Oligocene, and that the seaway to the Arctic Ocean was open. Leg 104 reports indicate that calcareous oozes appear at Site 643 in the lower Miocene (lithological Unit III) and on the Vøring Plateau proper not until upper Miocene (Unit IID) (Eldholm, Thiede, Taylor, et al., 1987). However, evidence for surface-water productivity in the form of siliceous oozes occurs a bit earlier on the plateau (Unit III). This evidence suggests that the productivity was quite variable across the plateau. Berggren and Schnitker (1981) believe the shift to calcareous sedimentation (Unit IID of Sites 643 and 642) signals the initiation of modern lagoonal circulation with NASW and NASW forma- 
Table 2. Percent of selected benthic foraminifer species* in Hole 642B.

\begin{tabular}{|c|c|c|c|c|c|c|c|c|c|c|c|c|c|c|c|c|}
\hline Sample (cm) & C. laevig & C. renif & C. subglob & E. excav & M. zaand & E. umbo & E. exigua & C. wuell & Cib spp & U. pygma & M. commun & Spirosi & Other & $\% \mathrm{BF}$ & No. $/ \mathrm{cm}^{3}$ & Zones \\
\hline $1-1,74-78$ & 62 & 23 & & 1 & 1 & 6 & & & & & & & 7 & 12 & 56.4 & \\
\hline $1-2,74-78$ & 18.8 & 5.8 & & 10.6 & 48.2 & 2.3 & 9.4 & & & & & & 5.9 & 12.7 & 4.7 & \\
\hline $1-3,74-78$ & 29 & 18 & & 19 & & & 1 & & & & & & 33 & 20 & 42 & \\
\hline 1, CC, $14-18$ & 33.9 & 9.7 & & & 0.4 & 7.8 & 2.1 & 16.1 & & & & & 30 & 3.4 & 187.6 & \\
\hline $2-2,36-40$ & 19 & 18 & & & 1 & 15 & 19 & 1 & & & & & 27 & & 92 & \\
\hline $2-3,36-40$ & 26.3 & 8.1 & 1 & 1 & 6.2 & 43.1 & 1 & & & & & & 13.1 & 1.8 & 46.4 & \\
\hline $2-4,36-40$ & 34 & 25 & & 9 & 4 & & 5 & 5 & & & & & 18 & 17 & 50 & \\
\hline $2-5,36-40$ & 39.8 & 4 & & 0.6 & 6.3 & 39.8 & 0.6 & 0.6 & & & & & 8.3 & 2.9 & 39.1 & \\
\hline $2-6,36-40$ & 35 & 35 & & & 13 & 5 & & & & & & & 22 & 19 & 17 & \\
\hline $2, \mathrm{CC}, 1-5$ & & Rare - & ot counted & & & & & & & & & & & & & \\
\hline $3-1,36-40$ & 3 & 38 & & & 1 & 15 & 1 & & & & & & 42 & 30 & 147 & \\
\hline $3-2,36-40$ & & Barren & & & & & & & & & & & & & & \\
\hline $3-3,36-40$ & 47 & 23 & & 9 & 1 & 3 & 13 & & & & & & 4 & 28 & 113 & \\
\hline $3-4,36-40$ & 50.3 & 15 & 0.3 & & 0.3 & 0.3 & 2.3 & 9.2 & & & & & 11.9 & 3.4 & 306 & \\
\hline $3, \mathrm{CC}, 9-13$ & 55 & 11 & & 1 & 1 & & 18 & 6 & & & & & 8 & 15 & 812 & \\
\hline $4-1,35-39$ & 51.1 & 14.6 & & 2.2 & 13.1 & 8.8 & & 2.2 & & & & & 8 & 7.4 & 17.1 & \\
\hline $4-2,35-39$ & 32 & 15 & & 6 & 5 & 2 & 20 & 1 & & & & & 19 & 8 & 44 & $\mathrm{~A} 1$ \\
\hline $4-3,35-39$ & 44.1 & 14.6 & 2.2 & 2.8 & 7.1 & & 1.8 & 11.2 & & & & & 16.2 & 18.5 & 53.7 & \\
\hline $4-4,35-39$ & 47 & 16 & & 2 & 1 & & 21 & & & & & & 13 & 26 & 51 & \\
\hline $4-5,35-39$ & & Barren & & & & & & & & & & & & & & \\
\hline $4-6,35-39$ & 23 & 10 & & 13 & 3 & 2 & 37 & & & & & & 12 & 42 & 153 & \\
\hline $4, \mathrm{CC}, 10-14$ & 21.8 & 15.5 & & 41.8 & 4 & & 8.4 & & & & & & 8.5 & 27.2 & 100 & \\
\hline $5-1,74-78$ & 20 & 18 & & 28 & 3 & & 19 & & & & & & 12 & 36 & 127 & \\
\hline $5-2,74-78$ & 39.7 & 21.4 & & 0.5 & 21.4 & 0.5 & 12.5 & & & & & & 4 & 27.7 & 49.8 & \\
\hline $5-3,74-78$ & & Barren & & & & & & & & & & & & & & \\
\hline $5-4,74-78$ & * & & & & & & & & & & & & & & & \\
\hline $5-5,74-78$ & & & & & * & & & & & & & & 0 & & 0.8 & \\
\hline $5-6,74-78$ & & Barren & & & & & & & & & & & & & & \\
\hline $5-7,74-78$ & 8 & 80 & & 1 & 3 & & 5 & & & & & & 3 & 25 & 154 & \\
\hline $5, \mathrm{CC}, 15-19$ & & Rare - & ot counted & & & & & & & & & & & & & \\
\hline $6-1,44-48$ & 36 & 49 & & 2 & 3 & & 2 & 2 & & & & & 6 & 17 & 223 & \\
\hline $6-2,44-48$ & & & & & * & & & & & & & & & & & \\
\hline $6-3,44-48$ & 33 & 56 & & & & & & & & & & & 11 & 33 & 8 & \\
\hline $6-4,44-48$ & & Barren & & & & & & & & & & & & & & \\
\hline $6-5,44-48$ & & Barren & & & & & & & & & & & & & & \\
\hline $6-6,44-48$ & & Barren & & & & & & & & & & & & & & \\
\hline $6, \mathrm{CC}, 18-22$ & & ++ & & & & & ++ & & & & & & 0 & 66 & 1.7 & \\
\hline $7-1,64-68$ & & Barren & & & & & & & & & & & & & & \\
\hline $7-2,64-68$ & & Barren & & & & & & & & & & & & & & \\
\hline $7-3,64-68$ & & Barren & & & & & & & & & & & & & & \\
\hline $7-4,64-68$ & & Barren & & & & & & & & & & & & & & \\
\hline $7-5,64-68$ & & Barren & & & & & & & & & & & & & & \\
\hline $7-6,64-68$ & & Barren & & & & & & & & & & & & & & Barren \\
\hline $7-7,64-68$ & & Barren & & & & & & & & & & & & & & \\
\hline 7, CC, $64-68$ & & Barren & & & & & & & & & & & & & & \\
\hline $8-1,64-68$ & & Barren & & & & & & & & & & & & & & \\
\hline $8-2,64-68$ & & & & * & & & & & & & & & 0 & 100 & 0.1 & \\
\hline $8-3,64-68$ & & Barren & & & & & & & & & & & & & & \\
\hline $8-4,64-68$ & & Barren & & & & & & & & & & & & & & \\
\hline $8-5,64-68$ & & Barren & & & & & & & & & & & & & & \\
\hline $8-6,64-68$ & & Barren & & & & & & & & & & & & & & \\
\hline $8, \mathrm{CC}, 10-14$ & & Barren & & & & & & & & & & & & & & \\
\hline $9-1,52-56$ & 1 & 2 & & & 8 & 3 & 84 & & & & & & 2 & 92 & 29 & \\
\hline $9-2,52-56$ & - & & & & * & & & & & & & & & & & \\
\hline $9-3,52-56$ & 25 & 26 & 2 & 11 & 11 & 4 & 8 & 1 & & & & & 12 & 60 & & \\
\hline $9-4,52-56$ & 2.6 & 8 & 2.1 & & 49.5 & & 4.9 & & 0.8 & & & & 32.1 & 39.7 & 21.6 & A2 \\
\hline $9-5,52-56$ & 12 & 10 & 4 & 5 & 34 & & 16 & & 3 & & & & 16 & 68 & 23.7 & \\
\hline $9-6,52-56$ & 1.8 & 5.2 & 12.7 & & 38.8 & & 15.8 & & 2.9 & & & & 22.8 & 52.3 & 24.2 & \\
\hline $9-7,52-56$ & 4 & 24 & 48 & 1 & 13 & 2 & 5 & & & & & & 3 & 57 & 68 & \\
\hline
\end{tabular}


Table 2 (continued).

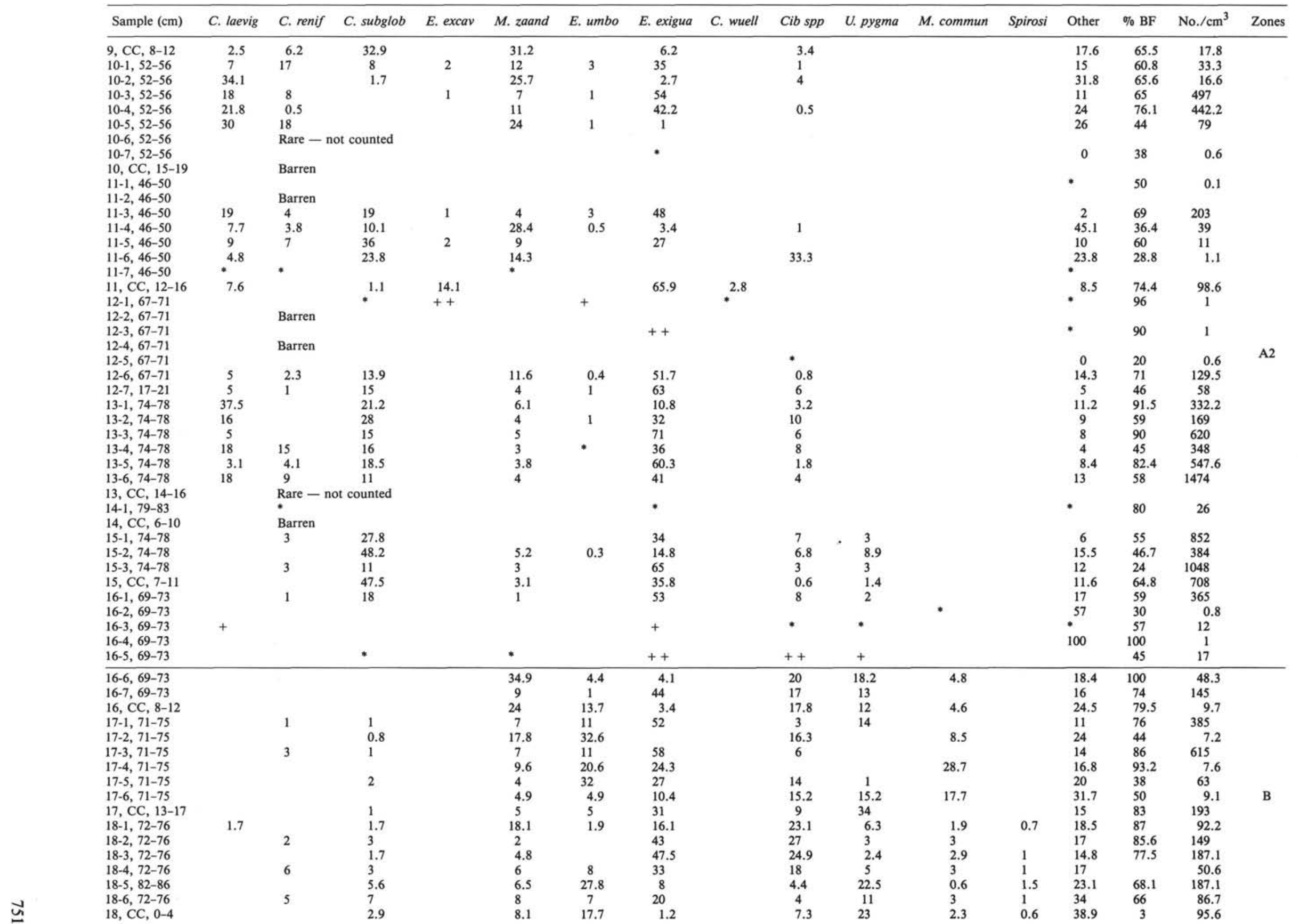


Table 2 (continued).

\begin{tabular}{|c|c|c|c|c|c|c|c|c|c|c|c|c|c|c|c|c|}
\hline Sample (cm) & C. laevig & C. renif & C. subglob & E. excav & M. zaand & E. umbo & E. exigua & C. wuell & Cib spp & U. pygma & M. commun & Spirosi & Other & $\% \mathrm{BF}$ & No. $/ \mathrm{cm}^{3}$ & Zones \\
\hline $19-1,72-76$ & & 3 & 3 & & 9 & 6 & 1 & & 8 & 32 & 1 & 1 & 36 & 71 & 43.7 & \\
\hline $19-2,89-93$ & & & 1.3 & & 3.7 & 28.9 & 0.7 & & 5.3 & 33.6 & 4.3 & 1.6 & 20.6 & 87.2 & 83.6 & \\
\hline $19-3,72-76$ & & & 3 & & 5 & & 6 & & 8 & 59 & 6 & 2 & 11 & 91 & 138.6 & $\mathbf{R}$ \\
\hline $19-4,72-76$ & & & 2.7 & & 2 & 14.8 & & & 2.7 & 61.6 & 4 & 0.7 & 11.5 & 88.7 & 148.5 & B \\
\hline $19-5,72-76$ & & & & & & & & & & & 40 & 40 & 20 & 100 & 8.8 & \\
\hline $19-6,72-76$ & & & & & & & & & & & 63.6 & 30.3 & 0 & 100 & 7.3 & \\
\hline 19, СС, $1-5$ & & & & & & & & & & & ++ & * & 0 & 77 & 2.2 & \\
\hline $20-1,71-75$ & & & & & & & & & & & 86.4 & 13.6 & 0 & 100 & 6.9 & \\
\hline $20-2,71-75$ & & & & & & & & & & & + & & 0 & 100 & 6.2 & \\
\hline $20-3,71-75$ & & & & & & & & & & & 100 & & 0 & 100 & 8.5 & \\
\hline $20-4,71-75$ & & & & & & & & & & & + & * & 0 & 88.8 & 7.1 & \\
\hline $20-5,71-75$ & & & & & & & & & & & 71.6 & 21.6 & 6.8 & 100 & 4.9 & \\
\hline $20-6,71-75$ & & & & & & & & & & & ++ & * & 0 & 100 & 12.4 & \\
\hline $20, \mathrm{CC}, 9-13$ & & & & & & & & & & & 84.9 & 15.1 & 0 & 100 & 6.6 & \\
\hline $21-1,74-78$ & & & & & & & & & & & + & $*$ & 0 & 100 & 1.8 & \\
\hline $21-2,74-78$ & & & & & & & & & & & ++ & & + & 100 & 2.1 & $C_{1}$ \\
\hline $21-3,74-78$ & & & & & & & & & & & + & * & 0 & 81.8 & 8 & $\mathrm{Cl}$ \\
\hline $21-4,74-78$ & & & & & & & & & & & + & ++ & 0 & 100 & 4 & \\
\hline $21-5,74-78$ & & & & & & & & & & & ++ & + & 0 & 82.3 & 2.8 & \\
\hline $21-6,74-78$ & & Barren & & & & & & & & & & & & & & \\
\hline $22-1,70-73$ & & & & & & & & & & & * & * & 0 & 100 & 3.5 & \\
\hline $22-2,70-73$ & & & & & & & & & & & ++ & + & * & 100 & 2.4 & \\
\hline $22-3,70-73$ & & & & & & & & & & & ++ & + & 0 & 86 & 9.6 & \\
\hline $22-4,70-73$ & & & & & & & & & & & ++ & ++ & $*$ & 100 & 5 & \\
\hline $22-5,70-73$ & & & & & & & & & & * & ++ & ++ & 0 & 86.8 & 1.8 & \\
\hline $22-6,70-73$ & & & & & 1 & & & & 0.9 & 36.1 & 29 & 27.3 & 5.7 & 99.6 & 29.7 & \\
\hline $22-7,34-37$ & & & & & & & & & & & 50 & 33.3 & 16.7 & 100 & 5.3 & \\
\hline $23-1,66-69$ & & & & & & & & & & & ++ & + & & 100 & 1.6 & \\
\hline $23-2,66-69$ & & & & & & & & & & & & + & 0 & 100 & 0.7 & \\
\hline $23-3,66-69$ & & & & & & & & & & & & + & 0 & 100 & 0.1 & \\
\hline $23-4,66-69$ & & & & & & & & & & & & : & 0 & 100 & 1.3 & \\
\hline $23-5,66-69$ & & & & & & & & & & & & + & 0 & 100 & 0.3 & \\
\hline $23-6,66-69$ & & & & & & & & & & & & * & 0 & 100 & 0.1 & \\
\hline $23-7,53-56$ & & & & & & & & & & & & + & 0 & 100 & 1.4 & \\
\hline $23, \mathrm{CC}, 5-8$ & & & & & & & & & & & & + & 0 & 100 & 2.2 & \\
\hline $24-1,66-69$ & & & & & & & & & & & & + & 0 & 100 & 0.3 & \\
\hline $24-2,66-69$ & & & & & & & & & & & & + & 0 & 100 & 0.6 & \\
\hline $24-3,66-69$ & & & & & & & & & & & & + & 0 & 100 & 0.2 & $\mathrm{C} 2$ \\
\hline $24-4,66-69$ & & & & & & & & & & & & + & 0 & 100 & 1 & \\
\hline $24-5,66-69$ & & & & & & & & & & & & + & 0 & 100 & 0.1 & \\
\hline $25-1,66-69$ & & & & & & & & & & & * & * & 0 & 100 & 0.1 & \\
\hline $25-2,66-69$ & & & & & & & & & & & & + & 0 & 100 & 0.2 & \\
\hline $25-3,66-69$ & & & & & & & & & & & + & * & 0 & 100 & 0.3 & \\
\hline $25-4,66-69$ & & & & & & & & & & & & + & 0 & 100 & 0.1 & \\
\hline $25-5,66-69$ & & & & & & & & & & & + & - & 0 & 100 & 0.16 & \\
\hline $25-6,66-69$ & & & & & & & & & & & & + & 0 & 100 & 0.1 & \\
\hline $25, \mathrm{CC}, 51-54$ & & & & & & & & & & & & & & & & \\
\hline
\end{tabular}

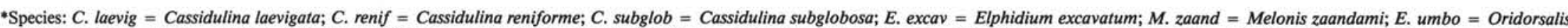
umbonatus; $E$. exigua $=$ Epistominella exigua $;$ C. wuell $=$ Cibicides wuellerstorfi; Cib spp = Cibicides spp.; U. pygma $=$ Uvigerina pygmaea $;$. commun $=$ Martinottiella communis; Spirosi $=$ Spirosigmoilinella sp. 
tion in the Norwegian Sea, which would correlate to our benthic Zone B.

During the late Oligocene to early Miocene, the continued opening of the Atlantic Ocean was responsible for increased upwelling and siliceous sedimentation in the Norwegian Sea. At this time long-ranging agglutinated foraminifers such as Spirolocammina, Spirosigmoilinella, and Martiottiella were established. The rare agglutinated foraminifers associated with Zone $\mathrm{C}$ most likely represent a taphonomic loss of the calcareous fauna due to a $\mathrm{pH}$ drop resulting from the high fertility and decay of siliceous organisms.

According to Berggren and Schnitker (1983) the early Miocene was a warm period, but cooling increased throughout the Miocene. Before that time the oceanic temperature is thought to have been more equally distributed and that during the Miocene thermal gradients of latitude and depth were established. This is in agreement with Murray (1984), who reported the initiation of early Miocene bottom-water mass similar to the NADW. In any regard the middle Miocene was a time of major atmospheric and oceanographic change, ending with the establishment of modern fauna by the late Miocene.

The middle Miocene establishment of modern benthic foraminifer species in Zone B appears to indicate the establishment of modern oceanic circulation. However, the presence of numerous holdover species, such as the Uvigerina and Cibicides species, suggests that the middle Miocene was a time of transitional water mass circulation with the modern glacial circulation becoming fully established in Zone A.

In contrast to the early Pliocene, the water masses of the late Pliocene and Pleistocene were more variable. Schnitker (1979, 1984) reported on major shifts in benthic foraminifer habitats of the Bay of Biscay brought about by climatically induced changes in the bottom water. Although the species found on the Vøring Plateau are often dissimilar to the abyssal species reported by Schnitker (1984), similar patterns of glacial/interglacial shifts are presently recognized (Osterman, 1987). One clear difference is the virtual lack of benthic foraminifers in the glacial-aged deposits of the Vøring Plateau. This research is in progress and will be reported at a later date.

The glacial section at Rockall (Murray, 1984) is also similar to those cored during Leg 104 in the occurrence of Cassidulina teretis ( $C$. laevigata); however, $C$. teretis is restricted to the glacial section on the Rockall margin, whereas in the Norwegian Sea it occurred before glaciation began at approximately $5 \mathrm{Ma}$.

Evidence for Cenozoic cooling is marked by the appearance of ice-rafted sediment around the middle Pliocene, the beginning of Zone A. The succession of glacial and interglacial periods is especially well demonstrated in Hole 644A, where intervals with a warm oceanic water assemblage including Cibicides wuellerstorfi and Cassidulina laevigata are interbedded with barren zones containing shallow-water species such as Elphidium excavatum as well as abundant ice-rafted material. Evidence for glaciation is also observed at Sites 642 and 643, but in a more condensed sequence.

\section{CONCLUSIONS}

Study of the Vøring Plateau samples from Sites 642, 643, and 644 has enabled us to establish a benthic foraminifer zonation for the Norwegian Sea from Eocene to Holocene (Fig. 2). This interval has been subdivided into seven zones and subzones, each characterized by a certain benthic foraminifer assemblage.

The interval deposited during the Eocene to middle Miocene contains almost exclusively agglutinated forms. This probably reflects a dissolution phenomenon rather than the living fauna. The lower part of the sediment sequence, deposited during Eocene and early Oligocene, is divided into assemblage Zones E and $\mathrm{D}$. This interval represents a period of rapid sedimentation with influx of shelf material.

Most of the lower to middle Miocene is characterized by high fertility evidenced by extensive biogenic silica sedimentation. The decay of the organic material is believed to be responsible for the resultant carbonate dissolution. The benthic foraminifer Zone $\mathrm{C}$ thus contains almost exclusively agglutinated forms. This assemblage zone, with Spirosigmoilinella spp. and Martinottiella communis, seems to be restricted to the Norwegian and North Seas. Martinottiella communis is not observed in the samples from the deepest site (Site 643) and may be restricted to shallower water.

Zone B represents the transitional assemblage between the Oligocene-lower Miocene fauna and the modern species developing during that time. The middle Miocene was also a period of major climatic and oceanographic changes with the establishment of the modern oceanographic circulation. The uppermost Zone, A, is characterized by a modern assemblage.

The onset of the last glaciation during the middle Pliocene is clearly reflected in the benthic foraminifer fauna. Intervals with ice-rafted particles and shallow-water foraminifers occur frequently, with zones containing a modern temperate water fauna in between.

\section{ACKNOWLEDGMENTS}

We wish to thank the captain and crew of the JOIDES Resolution, Co-chiefs Olav Eldholm and Jørn Thiede, and our fellow shipboard scientists of Leg 104. We would like to thank the JOIDES organization for the opportunity to participate in ODP. We thank F. Gradstein and D. Schnitker for reviewing our manuscript, and M. Buzas and L. Valulis for assistance while in residence at the Smithsonian Institution. Funding was provided by a USSAC grant from JOI, a Smithsonian Institution Postdoctoral Fellowship, and The George Washington University Facilitating Fund.

\section{REFERENCES}

Belanger, P. E., and Streeter, S. S., 1980. Distribution of benthic foraminifera in the Norwegian-Greenland Sea. Mar. Micropaleont., 5: 401-428.

Berggren, W. A., and Schnitker, D., 1983. Cenozoic marine environments in the North Atlantic and Norwegian-Greenland Sea. In Bott, M. H. P., Talwani, M., Thiede, J., and Saxov, S. (Eds.), Structure and Development of the Greenland-Scotland Ridge. New Methods and Concepts: Plenum Press, New York, 495-548.

Eldholm, O., Thiede, J., Taylor, E., et al., 1987. Proc. ODP, Init. Repts., 104: College Station, TX (Ocean Drilling Program).

Gradstein, F. M., and Berggren, W. A., 1981. Flysch-type agglutinated foraminifera and the Maestrichtian to Paleogene history of the Labrador and North Seas. Mar. Micropaleontol., 6:211-268.

Hermelin, J. O. R., and Scott, D. B., 1985. Recent benthic foraminifera from the central North Atlantic. Micropaleontology, 31:199-220.

Kaminski, M. A., Gradstein, F. M., Berggren, W. A., Geroch, S., and Beckman, J. P., 1988. Flysch-type agglutinated assemblages from Trinidad: taxonomy, stratigraphy and paleobathymetry. In Rögl, F., and Gradstein, F. M., (Eds.), Proceedings on 2nd Workshop on Agglutinated Foraminifera. Abh. Geol., Bundesanst., 41:155-228.

King, C., 1983. Cainozoic micropalaenotological biostratigraphy of the North Sea. Inst. Geol. Sci. Rep., 82: London.

Lagoe, M. B., 1977. Recent benthic foraminifera from the central Arctic Ocean. J. Foram. Res., 7:106-129.

Miller, K. G., and Tucholke, B. E., 1983. Development of Cenozoic abyssal circulation south of the Greenland-Scotland Ridge. In Bott, M. H. P., Talwani, M., Thiede, J., and Saxov, S. (Eds.), Structure and development of the Greenland-Scotland Ridge. New Methods and concepts: New York (Plenum Press), 549-590.

Miller, K. G., Gradstein, F. M., and Berggren, W. A., 1982. Late Cretaceous to early Tertiary agglutinated benthic foraminifera in the Labrador Sea. Micropaleontology, 28: 1-30.

Murray, J. W., 1984. Paleogene and Neogene benthic foraminifers from the Rockall Plateau. In Roberts, D. G., Schnitker, D., et al., Init. Repts. DSDP, 81: Washington (U.S. Govt. Printing Office), 503534. 
Mutter, J. C., Talwani, M., and Stoffa, P. L., 1984. Evidence for a thick oceanic crust adjacent to the Norwegian margin. J. Geophys. Res., 89:483-502.

Murray, J. W., 1987. Benthic foraminifers and Neogene bottom-water masses at Deep Sea Drilling Project Leg 94 North Atlantic Sites. In Ruddiman, W. F., Kidd, R. B., Thomas, E., et al., Init. Repts. DSDP, 94: Washington (U.S. Govt. Printing Office), 965-980.

Osterman, L., 1987. Glacial-Interglacial fluctuations in the Norwegian Sea. Int. Union Quaternary Res., XII Int. Cong., 235. (abstract).

Peterson, W. H., and Rooth, C. G. H., 1976. Formation and Exchange of deep water in the Greenland and Norwegian Seas. Deep Sea Res., 23:273-283.

Schnitker, D., 1979. Cenozoic deepwater benthic foraminifers, Bay of Biscay. In Montadert, L., Roberts, D. G., et al., Init. Repts. DSDP, 48: Washington (U.S. Govt. Printing Office), 377-414.

Schnitker, D., 1980. North Atlantic oceanography and its deep-water linkage to the Antarctic glaciation. Earth Sci. Rev., 16:1-20.

Schnitker, D., 1984. High resolution records of benthic foraminifers in the late Noegene of the northeastern Atlantic. In Roberts, D. G., Schnitker, D., et al., Init. Repts. DSDP, 81: Washington (U.S. Govt. Printing Office), 611-622.

Talwani, M., Udintsev, G., et al., 1976. Init. Repts. DSDP, 38: Washington (U.S. Govt. Printing Office).

Verdenius, J. G., and van Hinte, J. E., 1983. Central Norwegian Greenland Sea: Tertiary arenaceous foraminifera, biostratigraphy and environment. In Verdenius, J. G., van Hinte, J. E., and Fortuin, A. R. (Eds.), Proc. Workshop on Arenaceous Foraminifera 1st, 7-9 Sept. 1981, Cont. Shelf Inst. (IKU) Publ., 108: Trondheim, Norway, 173225.

Worthington, L. V., 1970, The Norwegian Sea as a Mediterranean Basin. Deep-Sea Res., 17, 77-88.

Date of initial receipt: 24 August 1987

Date of acceptance: 16 March 1988

Ms 104B-159

\section{APPENDIX}

Faunal Reference List

Anomalinoides alazanensis (Nuttall) = Anomalina alazanensis Nuttall, 1930.

Ammosphaeroidina pseudopauciloculata $(\mathrm{Mjatliuk})=$ Cystamminella pseudopauciloculata Mjatliuk, 1966.

Bolivina ?cataniensis Seguenza, 1862.

Buccella frigida (Cushman) = Pulvinulina frigida Cushman, 1922.

Bulimina marginata d'Orbigny, 1826.

Globocassidulina spherica Eade, 1967.

Cassidulina laevigata d'Orbigny, 1826.

Cassidulina reniforme Nørvang, 1945.

Cassidulina subglobosa Brady, 1881.
Cassidulina teretis Tappan, 1951.

Cibicides grimsdalei Nuttall, 1930.

Cibicides kullenbergi Parker, 1953.

Cibicides lobatulus (Walker \& Jacob) = Nautilus lobatulus Walker \& Jacob, 1798.

Cibicides lobatulus var. grossa ten Dam \& Reinhold, 1499.

Cibicides pseudoungeriana (d'Orbigny) = Truncatulina pseudoungerianus Cushman, 1922.

Cibicides wuellerstorfi (Schwager) = Anomalina wuellerstorfi Schwager, 1866.

Cyclammina amplectens Grzybowski, 1898.

Cyclammina cancellata Brady, 1879.

Cyclammina placenta (Reuss) = Nonionina placenta Reuss, 1851.

Cyclammina rotundidorsata (Hantken) = Haplophragmoides rotundidorsatum Hantken, 1875.

Elphidium excavatum $($ Terquem) = Polystomella excavata Terquem, 1876.

Epistominella exigua $($ Brady) $=$ Pulvinulina exigua Brady, 1884 .

Eponides tumidulus (Brady) = Truncatulina tumidula, Brady, 1884 .

Glabratella crassa Dorreen, 1948.

Haplophragmoides kirki Wickenden, 1932.

Haplophragmoides walteri (Grzybowski) = Trochammina walteri Grzybowski, 1898.

Martinottiella communis (d'Orbigny) = Clavulina communis d'Orbigny, 1846.

Melonis zaandami (van Voorthuysen) = Nonion zaandamae van Voorthuysen, 1952.

Neogloboquadrina pachyderma (Ehrenberg) = Aristerospira pachyderma Ehrenberg, 1861.

Oolina melo d'Orbigny, 1839.

Oridorsalis umbonatus (Reuss) = Rotalina umbonata, Reuss, 1851 .

Praecystammina globigerinaeformis Krasheninnikov, 1973.

Pullenia bulloides (d'Orbigny) = Nonionina bulloides d'Orbigny, 1826.

Pullenia quinqueloba (Reuss) = Nonionina quinqueloba Reuss, 1851 .

Pyrgo murrhina (Schwager) = Biloculina murrhina Schwager, 1986.

Pyrgo williamsoni (Silvestri) = Biloculina williamsoni Silvestri, 1923.

Recurvoides contortus Earland, 1934.

Recurvoides deflexiformis (Noth) = Trochammina deflexiformis Noth, 1912.

Reophax subnodulosus Grzybowski, 1898.

Spiroplectammina spectabilis (Grzybowski) = Spiroplecta spectabilis Grzybowski, 1898.

Stainforthia loeblichi (Feyling-Hanssen) = Virgulina loeblichi FeylingHanssen, 1954.

Stetsonia horvathi Green, 1959.

Triloculina trihedra Loeblich \& Tappan, 1953.

Trochammina altiformis (Cushman \& Renz) = Trochammina globigeriniformis (Parker \& Jones) var. altiformis Cushman \& Renz, 1946.

Turrilina alsatica Andreae, 1884.

Uvigerina auberiana d'Orbigny, 1839.

Uvigerina pygmaea d'Orbigny, 1839. 
Table 3. Percent of selected benthic foraminifer species* in Hole $642 \mathrm{C}$.

\begin{tabular}{|c|c|c|c|c|c|c|c|c|c|c|c|c|}
\hline Sample (cm) & C. laevig & C. renif & G. subglob & E. excav & M. zaand & E. umbo & E. exigua & C. wuell & Cib spp & U. pygma & M. commun & Spirosi \\
\hline $1-2,82-86$ & - & & & - & & & & & & & & \\
\hline $1, \mathrm{CC}, 7-11$ & + & & & - & & & & * & & & & \\
\hline $2-2,28-32$ & + & & & & + & & & & & & & \\
\hline $2-4,28-32$ & & & Barren & & & & & & & & & \\
\hline $2-6,28-32$ & & & Barren & & & & & & & & & \\
\hline $2, \mathrm{CC}, 7-11$ & 48.4 & 2.6 & & & 8.5 & 17 & & & & & & \\
\hline $3-2,28-32$ & • & & & - & & & & & & & & \\
\hline $3-4,28-32$ & $*$ & & & & - & & & & & & & \\
\hline $3-6,28-32$ & 94.3 & 3.9 & & 1.3 & & & & & & & & \\
\hline $3, \mathrm{CC}, 13-17$ & 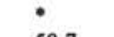 & & & & & & & & & & & \\
\hline $4-2,53-57$ & 50.7 & 6.7 & & 42.2 & & & & & & & & \\
\hline $4-4,53-57$ & 75.4 & 2.7 & & 0.5 & 20.9 & 0.5 & & & & & & \\
\hline $4-6,53-57$ & 79.3 & 5.4 & & & 8.7 & & & 8.2 & & & & \\
\hline & - & & Barren & & & & & & & & & \\
\hline $\begin{array}{l}5-2,67-71 \\
5-4,67-71\end{array}$ & & & Barren & & & & & & & & & $\bullet$ \\
\hline $\begin{array}{l}5-4,67-71 \\
5-6,67-71\end{array}$ & & & Barren & & & & & & & & & \\
\hline & & & Barren & & & & & & & & & \\
\hline $\begin{array}{l}6-1,67-71 \\
6-3,67-71\end{array}$ & & & Barren & & & & & & & & & \\
\hline $6-5,67-71$ & & & Barren & & & & & & & & & \\
\hline $6, C C, 25-29$ & & & Barren & & & & & & & & & \\
\hline $7-2,74-78$ & & & & - & & & & & & & & \\
\hline $7-4,74-78$ & & & Barren & & & & & & & & & \\
\hline $8-1,74-78$ & & & Barren & & & & & & & & & \\
\hline $8, C C, 14-18$ & 28.5 & 8.8 & 0.4 & & 9.4 & 4 & 38.7 & & 3.8 & & & \\
\hline $9-2,73-79$ & 37.1 & 16.5 & 3.7 & & 7.8 & & 12.7 & & 11.2 & & & \\
\hline $10-1,77-81$ & & & Barren & & & & & & & & & \\
\hline $10-3,77-81$ & 32.7 & 10.1 & 2 & & 14.7 & 0.2 & & & & & & \\
\hline $10-5,77-81$ & 51.4 & 17.1 & 2.3 & & 8.4 & 1.8 & 3.6 & & 5.6 & & & \\
\hline $10-6,77-81$ & 25 & & & 0.3 & 47.8 & & 3.7 & & 0.7 & & & \\
\hline 10, CC, $9-13$ & 24.1 & 6 & 6.9 & & 47.1 & & & & 0.3 & & & \\
\hline $11-2,74-78$ & 29.6 & 10.4 & 19.7 & & 21.9 & & 4.3 & & 2.8 & & & \\
\hline $11-4,74-78$ & $\cdot$ & & & & 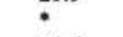 & & & & & & & \\
\hline $11-6,74-78$ & 48.9 & 0.7 & & & 14.6 & 0.4 & 22.3 & & 1.4 & & & \\
\hline $12-1,73-77$ & 38.5 & 0.5 & 1.7 & & 15.8 & & 1.3 & & 2 & & & \\
\hline $12-3,73-77$ & $\cdot$ & & & & $\cdot$ & & & & & & & \\
\hline $12-5,73-77$ & & & Barren & & & & & & & & & \\
\hline $12, \mathrm{CC}, 16-20$ & & & Barren & & & & & & & & & \\
\hline $13-2,74-78$ & & & & & & & & & & & * & \\
\hline $14-1,73-77$ & & & & & & & & & & & & \\
\hline $14-3,73-77$ & 35.9 & & 19.2 & & 12.5 & & 3.2 & & 5.6 & & & 0.7 \\
\hline $14-5,73-77$ & 22.8 & & 34.6 & & 7.7 & 1.2 & 1.6 & & & & & \\
\hline 14, CC, $24-26$ & 16.2 & & 22.8 & & 2.8 & 0.2 & & & 2.3 & & & 0.2 \\
\hline $15-2,74-78$ & & & Barren & & & & & & & & & \\
\hline $15-4,74-78$ & & & Barren & & & & & & & & & \\
\hline $15-6,74-78$ & & & Barren & & & & & & & & & \\
\hline $16-2,74-78$ & & & 43.5 & & 4.4 & 0.4 & 31.5 & & 8.1 & 2.5 & & \\
\hline $16-4,74-78$ & 21.2 & & & & 7.1 & & 60.1 & & 5.3 & 0.9 & & \\
\hline $16-6,69-73$ & & & & & & & & & & & $*$ & + \\
\hline $17-1,72-75$ & & & & & & & & & & & & $\bullet$ \\
\hline $17-3,72-75$ & & & 0.6 & & 17.2 & 27.3 & 14.4 & & 11.8 & 6.9 & & 0.6 \\
\hline $17-6,72-75$ & & & 0.7 & & 27.9 & 28.3 & 13.6 & & 11.3 & 7.9 & & \\
\hline $18-1,78-81$ & & & 0.3 & & 7.1 & 35 & 33.1 & & 3.1 & & 0.9 & \\
\hline $18-3,78-81$ & & & & & 2.9 & 18.4 & 1.9 & & 20.4 & 15.5 & 8.9 & 2.9 \\
\hline $18-5,78-81$ & & & 1.1 & & 7.1 & 13.5 & 16.2 & & 40.6 & 5.6 & 3.4 & \\
\hline $18, C C, 10-13$ & & & & & & & $\cdot$ & & $\cdot$ & & $*$ & \\
\hline $19-2,68-71$ & & & 13 & & 7.6 & 14.8 & 8.9 & & 23.1 & 4.7 & 4.7 & 2.4 \\
\hline $19-4,68-71$ & & & 8.3 & & 8.7 & 20.4 & & & 12.8 & 17 & 5.7 & 3.7 \\
\hline $19-6,68-71$ & & & 3.8 & & 12.5 & 27.4 & 3.8 & & 3.1 & 24.9 & & 0.6 \\
\hline 19, CC, $46-49$ & & & & & 9.8 & 1.8 & & & 8.5 & 48.8 & 7.9 & 2.4 \\
\hline $20-2,72-75$ & & & & & & & & & & & +++ & \\
\hline $20-4,72-75$ & & & & & & & & & & & 60 & 36.1 \\
\hline $20-6,72-75$ & & & & & & & & & & & 81 & 16.5 \\
\hline 20, CC, $36-39$ & & & & & & & & & & & & + \\
\hline $21-2,78-81$ & & & & & & & & & & & + & $\bullet$ \\
\hline $21-4,78-81$ & & & & & & & & & & + & + & + \\
\hline $21-6,78-81$ & & & & & & & & & & & $*$ & $\bullet$ \\
\hline $22-1,83-86$ & & & & & & & & & & & $*$ & \\
\hline $22-3,78-81$ & & & & & & & & & & & 62.2 & 37.8 \\
\hline $22-5,64-67$ & & & & & & & & & & & $*$ & * \\
\hline $23-2,78-81$ & & & & & & & & & & & * & \\
\hline $23-4,78-81$ & & & & & & & & & & & * & \\
\hline $23, \mathrm{CC}, 29-32$ & & & & & & & & & & & * & \\
\hline $24-2,78-81$ & & & & & & & & & & & * & * \\
\hline $24-4,78-81$ & & & & & & & & & & & & * \\
\hline $24, \mathrm{CC}, 78-81$ & & & & & & & & & & & & * \\
\hline
\end{tabular}

*Species: C. laevig $=$ Cassidulina laevigata $;$. renif $=$ Cassidulina reniforme; $C$. subglob $=$ Cassidulina subglobosa $;$ E. excav $=$ Elphidium excavatum; $M$. zaand $=$ Melonis zaandami; $E$. umbo $=$ Oridorsalis umbonatus; $E$. exigua $=$ Epistominella exigua $; C$. wuell =Cibicides wuellerstorfi; Cib spp $=$ Cibicides spp.; $U$. pygma = Uvigerina pygmaea,$M$. commun = Martinottiella communis; Spirosi $=$ Spirosigmoilinella $\mathrm{sp}$. 
Table 3 (continued).

\begin{tabular}{llccc}
\hline Sample $(\mathrm{cm})$ & Others & $\%$ BF & No./ $\mathrm{cm}^{3}$ & Zones \\
\hline $1-2,82-86$ & & & & \\
1, CC, $7-11$ & 0 & 1 & 0.6 & \\
$2-2,28-32$ & 0 & 1 & 3.7 & \\
$2-4,28-32$ & & & & \\
$2-6,28-32$ & & & & \\
2, CC, $7-11$ & 5.9 & 1 & 9.3 & A1 \\
$3-2,28-32$ & 0 & $<1.0$ & & \\
$3-4,28-32$ & 0 & $<1.0$ & & \\
$3-6,28-32$ & 0.5 & 21.2 & 536.5 & \\
3, CC, $13-17$ & 0 & & & \\
$4-2,53-57$ & 0.4 & 40.4 & 128.6 & \\
$4-4,53-57$ & 0 & 37.8 & 116.9 & \\
$4-6,53-57$ & 3.8 & 5.3 & 408.9 & \\
\hline
\end{tabular}

\begin{tabular}{ll}
\hline $4, C C, 1-5$ & \\
$5-2,67-71$ & 0 \\
$5-4,67-71$ & \\
$5-6,67-71$ &
\end{tabular}

6-1, 67-71

$\begin{array}{ll}6-3,67-71 & \text { Barren } \\ 6-5,67-71 & \end{array}$

$6, \mathrm{CC}, 25-29$

$7-2,74-78$

$7-4,74-78$
$8-1,74-78$

\begin{tabular}{lrlc}
\hline $8, \mathrm{CC}, 14-18$ & 6.4 & 94.2 & 27.8 \\
$9-2,73-79$ & 6.8 & 87.5 & 35.7 \\
$10-1,77-81$ & & & \\
$10-3,77-81$ & 10.4 & 90.2 & 140 \\
$10-5,77-81$ & 9.7 & 91.8 & 97.8 \\
$10-6,77-81$ & 44.8 & 70.1 & 14.4 \\
$10, \mathrm{CC}, 9-13$ & 12.9 & 71.4 & 28.8 \\
$11-2,74-78$ & 11.3 & 82.6 & 51.3 \\
$11-4,74-78$ & $*$ & & \\
$11-6,74-78$ & 23.4 & & 222 \\
$12-1,73-77$ & 21 & 85.6 & 22.5 \\
$12-3,73-77$ & $*$ & 67 & 0.2
\end{tabular}

$12-3,73-77$
$12-5,73-77$

$12-5,73-77$
$12, \mathrm{CC}, 16-20$

13-2, 74-78

$14-1,73-77$

$14-1,73-77$

$\begin{array}{llll}14-3,73-77 & 45.7 & 89.3 & 56.3\end{array}$

$\begin{array}{lrrr}14-5,73-77 & 22 & & 27.3 \\ 14, \text { CC }, 24-26 & 4 & 82.7 & 354.2\end{array}$

$15-2,74-78$

$15-4,74-78$

$15-6,74-78$

$16-2,74-7$

\begin{tabular}{cccc}
$16-2,74-78$ & 21.3 & 73.1 & 60 \\
$16-4,74-78$ & 5.3 & 67.1 & 361.7 \\
\hline $16-6,69-73$ & 0 & 81.8 & 0.5 \\
$17-1,72-75$ & 0 & & 0.06
\end{tabular}

$17-1,72-75 \quad 0 \quad 0.06$

$\begin{array}{llll}17-3,72-75 & 21.3 & 89.7 & 193.3\end{array}$

$\begin{array}{lrrr}17-6,72-75 & 4.9 & 66.9 & 36.8\end{array}$

$\begin{array}{rrrr}18-1,78-81 & 10.8 & 90.9 & 161.5\end{array}$

$\begin{array}{lllr}18-3,78-81 & 29.1 & 100 & 5.7\end{array}$

$\begin{array}{llll}18-5,78-81 & 12.4 & 89.6 & 44.3\end{array}$

$\begin{array}{lllr}18, \mathrm{CC}, 10-13 & \bullet & 70 & 0.3 \\ 19-2,68-71 & 18.9 & 88.5 & 46.9\end{array}$

$\begin{array}{llll}19-2,68-71 & 18.9 & 88.5 & 46.9 \\ 19-4,68-71 & 46.8 & 52.6 & 14.7\end{array}$

$\begin{array}{llll}19-6,68-71 & 19.3 & 72.6 & 89.2\end{array}$

\begin{tabular}{lllr}
$19, \mathrm{CC}, 46-49$ & 12.2 & 95.3 & 45.6 \\
\hline
\end{tabular}

20-2, 72-75 *

$20-4,72-75 \quad 2.8$

$\begin{array}{llll}20-6,72-75 & 2.5 & 100 & 5.8 \\ \end{array}$

20, CC, 36-39 * $\quad 100 \quad 2.1$

$21-2,78-81 * 000$

$21-4,78-81+100 \quad 3$
$21-6,78-81$

$21-6,78-81$

$22-1,83-86$

$22-3,78-81$

22-5, 64-67

23-2, 78-81

$23-4,78-8$

23, CC, 29-32

24-2, 78-81

24-4, 78-8

24, CC, 78-81

B

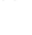

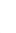

.7

0.2

.2

C1
Table 4. Percent of selected benthic foraminifer species* in Hole 642D.

\begin{tabular}{|c|c|c|c|c|c|c|}
\hline Sample $(\mathrm{cm})$ & M. comm & Spirosi & Other & $\%$ BF & No. $/ \mathrm{cm}^{3}$ & Zones \\
\hline $2-1,73-77$ & $*$ & + & $\bullet$ & 67 & 1.8 & \\
\hline $2-2,73-77$ & ++ & ++ & + & 100 & 2.9 & \\
\hline $\begin{array}{l}2-3,73-77 \\
2-4,73-77\end{array}$ & $\begin{array}{l}\text { Barren } \\
\text { Barren }\end{array}$ & & & & & $\mathrm{Cl}$ \\
\hline $\begin{array}{l}2-4,73-77 \\
2-5,73-77\end{array}$ & $\begin{array}{l}\text { Barren } \\
12.5\end{array}$ & 81.3 & 6.2 & 88.8 & 14.2 & \\
\hline $2-6,73-77$ & +++ & ++ & $\begin{array}{l}0.2 \\
+\end{array}$ & 100 & $\begin{array}{r}14.2 \\
4.3\end{array}$ & \\
\hline $2, \mathrm{CC}, 4-8$ & & + & 0 & 100 & 0.9 & \\
\hline $3-1,73-77$ & • & $\bullet$ & 0 & 100 & 0.1 & \\
\hline $3-2,73-77$ & & + & 0 & 100 & 0.6 & \\
\hline $3-3,73-77$ & & ++ & 0 & 100 & 0.6 & \\
\hline $3-4,73-77$ & & + & 0 & 100 & 0.6 & \\
\hline $3-5,73-77$ & & + & 0 & 100 & 0.2 & \\
\hline 3, CC, $5-9$ & & ++ & 0 & 100 & 1.9 & \\
\hline $4-1,73-77$ & Barren & & & & & \\
\hline $4-2,73-77$ & & + & 0 & 100 & 0.8 & \\
\hline $4-3,73-77$ & & + & 0 & 100 & 0 & \\
\hline $4-4,73-77$ & * & ++ & 0 & 100 & 1.4 & \\
\hline $4-5,73-77$ & & + & 0 & 100 & & \\
\hline $4-6,73-77$ & & + & 0 & 100 & 0.8 & \\
\hline $4, C C, 4-6$ & Barren & & & & & \\
\hline $5-1,74-78$ & & + & 0 & 100 & 0.8 & \\
\hline $5-2,74-78$ & & + & 0 & 100 & & \\
\hline $5-3,74-78$ & & + & 0 & 100 & 0.5 & \\
\hline $5-4,74-78$ & & + & 0 & 100 & 0.1 & \\
\hline $5-5,74-78$ & & + & 0 & 100 & & \\
\hline $5-6,74-78$ & & + & 0 & 100 & 0.1 & \\
\hline $5, C C, 11-15$ & & + & 0 & 100 & 0.5 & \\
\hline $6-1,75-79$ & Barren & - & & 100 & & \\
\hline $6-2,75-79$ & & - & $\begin{array}{l}0 \\
0\end{array}$ & 100 & 0.3 & \\
\hline $\begin{array}{l}6-3,75-79 \\
6-4,75-79\end{array}$ & Barren & & & & & \\
\hline $\begin{array}{l}6-4,75-79 \\
6-5,75-79\end{array}$ & & * & 0 & 100 & 0.05 & \\
\hline $7-1,74-78$ & & ++ & 0 & 100 & 0.8 & \\
\hline $7-2,74-78$ & Barren & & & & & $\mathrm{C} 2$ \\
\hline $7-3,74-78$ & & + & 0 & 100 & 0.3 & \\
\hline $7-4,74-78$ & & - & 0 & 100 & & \\
\hline $7-5,74-78$ & & ++ & 0 & 100 & 1.7 & \\
\hline $7-6,74-78$ & & + & 0 & 100 & & \\
\hline $7, \mathrm{CC}, 4-8$ & & + & 0 & 100 & 0.2 & \\
\hline $8-1,73-77$ & & ++ & 0 & 100 & 2.5 & \\
\hline $8-2,73-77$ & & 100 & 0 & 100 & 9.3 & \\
\hline $8-3,73-77$ & & + & 0 & 100 & & \\
\hline $8-4,73-74$ & & + & 0 & 100 & 0.5 & \\
\hline $8-5,73-77$ & & + & 0 & 100 & 0.9 & \\
\hline $8-6,73-77$ & Barren & & & & & \\
\hline $8, \mathrm{CC}, 17-21$ & & $\bullet$ & 0 & 100 & 0.2 & \\
\hline $9-1,78-81$ & & +++ & 0 & 81.8 & 4 & \\
\hline $9-2,80-83$ & & $\cdot$ & 0 & 100 & & \\
\hline $9-3,78-81$ & & ++ & - & 77.4 & 1.3 & \\
\hline $9-4,78-81$ & & $*$ & 0 & 100 & 0.06 & \\
\hline $9-5,78-81$ & & ++ & - & 78.2 & 2.4 & \\
\hline $9-6,78-81$ & & $\cdot$ & 0 & 100 & 0.8 & \\
\hline $9-7,24-27$ & & ++ & 0 & 72.2 & 1.4 & \\
\hline $9, \mathrm{CC}, 21-24$ & & • & 0 & 100 & 1.1 & \\
\hline $10-1,60-63$ & & $\bullet$ & 0 & 100 & 0.2 & \\
\hline $10-2,60-63$ & & $\bullet$ & 0 & 100 & & \\
\hline $10-3,60-63$ & Barren & & & & & \\
\hline $10-4,60-63$ & & $\bullet$ & 0 & 100 & & \\
\hline $10-5,60-63$ & & ++ & 0 & 100 & 4.2 & \\
\hline $10-6,60-63$ & Barren & & & & & \\
\hline $10, \mathrm{CC}, 5-8$ & & ++ & ++ & 0 & 2.1 & \\
\hline $11-1,62-65$ & Barren & & & & & \\
\hline $11-2,62-65$ & Barren & & & & & \\
\hline $11, \mathrm{CC}, 20-23$ & Barren & & & & & \\
\hline $12-1,78-81$ & Barren & & & & & \\
\hline $12-2,78-81$ & Barren & & & & & \\
\hline $12-3,78-81$ & Barren & & & & & \\
\hline $12-5,45-49$ & Barren & & & & 0.05 & \\
\hline $12-5,78-81$ & & $*$ & 0 & 100 & & \\
\hline $12.6,78-81$ & Barren & & & & & Barren \\
\hline $12, \mathrm{CC}, 20-23$ & Barren & & & & & \\
\hline $13-1,78-81$ & Barren & & & & & \\
\hline $13-2,78-81$ & Barren & & & & & \\
\hline $13-3,78-81$ & Barren & & & & & \\
\hline $13-4,78-81$ & Barren & & & & & \\
\hline $13, \mathrm{CC}, 20-23$ & Barren & & & & & \\
\hline $14-1,0-4$ & Barren & & & & & \\
\hline $14-1,75-79$ & Barren & & & & & \\
\hline $\begin{array}{l}15, \text { CC, } 0-4 \\
16-1,1-4\end{array}$ & $\begin{array}{l}\text { Barren } \\
\text { Barren }\end{array}$ & & & & & \\
\hline
\end{tabular}

*Species: $M$. comm = Martinottella communis; Spirosi $=$ Spirosigmoilinella $\mathrm{sp}$. 
Table 5. Percent of selected benthic foraminifer species in Hole 643A.

\begin{tabular}{|c|c|c|c|c|c|c|c|c|c|c|c|c|c|c|c|c|c|}
\hline Sample $(\mathrm{cm})$ & E. umbo & C. wuell & C. subgl & E. exigua & C. laevig & M. zaand & Cib spp & Spiroloc & Trocham & Tubes & Spirosi & Haploph & Cyclam & Other & $\% \mathrm{BF}$ & No. $/ \mathrm{cm}^{3}$ & Zones \\
\hline $1-1,4-8$ & 4 & 10 & & & & & & & & & & & & 86 & & & \\
\hline $1-1,74-78$ & & & & & - & & & & & & & & & 0 & 0.01 & & \\
\hline $1-2,74-78$ & 2 & 9 & & & & & & & & & & & & 89 & 2 & 2898 & \\
\hline $1-3,74-78$ & & & Barren & & & & & & & & & & & & & & \\
\hline $1, \mathrm{CC}, 10-14$ & ++ & & & & & & & & & & & & & ++ & 7.4 & 30 & \\
\hline $2-1,76-80$ & & & Barren & & & & & & & & & & & & & & \\
\hline $2-2,76-80$ & * & ++ & & & & & & & & & & & & ++ & 3 & 65.3 & \\
\hline $2-3,76-80$ & ++ & & & & + & & & & & & & & & ++ & 0.01 & 2.4 & \\
\hline $2-4,76-80$ & & * & & & & & & & & & & & & + & 1.4 & 0.9 & \\
\hline $2-5,76-80$ & & + & & & & & & & & & & & & + & 0.01 & 0.2 & \\
\hline $2-6,76-80$ & + & & & & & * & & & & & & & & +++ & 23 & 3.5 & Al \\
\hline $2, \mathrm{CC}, 10-14$ & & +++ & & & & & & & & & & & & 0 & 5 & 1 & \\
\hline $3-1,74-78$ & & & Barren & & & & & & & & & & & & & & \\
\hline $3-2,74-78$ & & 21.1 & 63.4 & & 1.5 & & 1.5 & & & & & & & 14 & 0.2 & 15.8 & \\
\hline $3-3,74-78$ & 1 & & & & & & & & & & & & & 99 & 50 & 85 & \\
\hline $3-4,74-78$ & & & & & & & & & & & & & & + & 0.01 & 0.1 & \\
\hline $3-5,74-78$ & & + & & & & & & & & & & & & $*$ & 15.8 & 0.3 & \\
\hline $3-6,74-78$ & & +++ & & & & & * & & & & & & & 0 & 9.3 & 2.8 & \\
\hline $3-7,34-38$ & & 27 & & & & & & & & & & & & 73 & 4.8 & 174.2 & \\
\hline $3, \mathrm{CC}, 9-13$ & & ++ & & & * & & * & & & & & & & 0 & 0.01 & 0.9 & \\
\hline $4-1,72-76$ & & & & & & & & & & & & & & 100 & 78.1 & 872 & \\
\hline $4-2,70-74$ & & & Barren & & & & & & & & & & & & & & \\
\hline $4-3,70-74$ & & & & & & & & & & & & & & * & 50 & 1.8 & \\
\hline $4-4,73-77$ & & & Barren & & & & & & & & & & & & & & \\
\hline $4-5,73-77$ & & * & & & & & & & & & & & & + & 10.3 & 1.8 & \\
\hline $4-6,71-75$ & & & & & & & & & & & & & & - & 0.01 & & \\
\hline $4-7,23-27$ & & & & & & & & & & & & & & * & 0 & 0.06 & \\
\hline $4, C C, 18-22$ & & & Barren & & & & & & & & & & & & & & \\
\hline $5-1,72-76$ & & & & & & & & & & & & & & + & 53.9 & 3.1 & \\
\hline $5-2,67-71$ & & & Barren & & & & & & & & & & & & & & \\
\hline $5-3,72-76$ & & & Barren & & & & & & & & & & & & & & Barren \\
\hline $5-4,72-76$ & & & Barren & & & & & & & & & & & & & & Barren \\
\hline $5-5,72-76$ & & & Barren & & & & & & & & & & & & & & \\
\hline $5-6,72-76$ & & & Barren & & & & & & & & & & & & & & \\
\hline $5, \mathrm{CC}, 14-20$ & & & & & & & & & & & & & & * & 100 & 0.6 & \\
\hline $6-1,75-79$ & & & Barren & & & & & & & & & & & & & & \\
\hline $6-2,75-79$ & * & & & & & & & & & & & & & + & 13.8 & 1.8 & \\
\hline $6-3,75-79$ & & & Barren & & & & & & & & & & & & & & \\
\hline $6-4,75-79$ & & & Barren & & & & & & & & & & & & & & \\
\hline $6-5,75-79$ & & & Barren & & & & & & & & & & & & & & \\
\hline $6-6,75-79$ & & & Barren & & & & & & & & & & & & & & \\
\hline $6, \mathrm{CC}, 14-19$ & & & Barren & & & & & & & & & & & & & & \\
\hline $7-1,74-78$ & & & Barren & & & & & & & & & & & & & & \\
\hline $7-2,74-78$ & 1.1 & & 1.3 & 46.9 & 35.2 & 9.9 & 2.7 & & & & & & & 2.9 & 98.4 & 83.3 & \\
\hline $7-3,74-78$ & & & & 14 & 46 & 12 & 1.3 & & & & & & & 26.7 & 98.5 & 549 & \\
\hline $7-4,74-78$ & 1.1 & & 0.3 & 57.1 & 15.8 & 5.4 & 7 & & & & & & & 10.5 & 96.1 & 82.9 & \\
\hline $7-5,74-78$ & 8 & & & 55 & 23 & 5 & & & & & & & & 9 & 75.9 & 172 & \\
\hline $7, \mathrm{CC}, 9-12$ & & & & & + & & * & & & & & & & ++ & 100 & 1.4 & A? \\
\hline $8-1,74-78$ & & & & ++ & * & * & & & & & & & & $\cdot$ & 84.2 & 1.8 & A2 \\
\hline $8-2,74-78$ & & & Barren & & & & & & & & & & & & & & \\
\hline $8-3,74-78$ & & & & * & & & & & & & & & & * & 75 & 0.2 & \\
\hline $8-4,74-78$ & & & Barren & & & & & & & & & & & & & & \\
\hline $8-5,74-78$ & & & Barren & & & & & & & & & & & & & & \\
\hline $\begin{array}{l}8-6,74-78 \\
8, \text { CC, } 10-14\end{array}$ & & & & & & & & & & & + & & & 0 & 100 & 0.06 & \\
\hline $9-1,73-77$ & 1.2 & & 6.8 & 21 & & 35.8 & 17.9 & & & & 3.1 & & & 15.6 & 75 & 9 & B \\
\hline $\begin{array}{l}9-2,73-77 \\
9-3,73-77\end{array}$ & & & Barren & & & & & & & & + & & & 0 & 25 & 0.06 & \\
\hline $9-4,73-77$ & & & & & & & & & & & + & & & 0 & 60 & 0.2 & \\
\hline
\end{tabular}


Table 5 (continued).

\begin{tabular}{|c|c|c|c|c|c|c|c|c|c|c|c|c|c|c|c|c|c|}
\hline Sample (cm) & E. umbo & C. wuell & C. subgl & E. exigua & C. laevig & M. zaand & Cib spp & Spiroloc & Trocham & Tubes & Spirosi & Haploph & Cyclam & Other & $\% \mathrm{BF}$ & No. $/ \mathrm{cm}^{3}$ & Zones \\
\hline $9-5,73-77$ & & & + & & & + & * & & & & * & & & - & 79 & 2 & \\
\hline $9-6,73-77$ & * & & * & * & & ++ & * & & & & * & & * & * & 79 & 2 & \\
\hline $9, \mathrm{CC}, 73-77$ & & & & & & + & ++ & & & & & & & + & 100 & 0.8 & \\
\hline $10-1,73-77$ & & & & & & ++ & & & & & & & & ++ & 100 & 8 & \\
\hline $10-2,73-77$ & & & & & & & * & & & & & & & $*$ & 100 & 0.3 & \\
\hline $10-3,73-77$ & & & & 10 & 0.3 & 23 & 6 & & & & 0.3 & & & 60.4 & 49 & 5.7 & \\
\hline $10-4,73-77$ & & & ++ & $*$ & & + & + & & & & & & & ++ & 2 & 2.5 & \\
\hline $10-5,73-77$ & & & & * & & * & & & & & & & & + & 8.5 & 0.4 & B \\
\hline $10-6,73-77$ & & & & & & & & & & & & & & * & 20 & 0.06 & \\
\hline $10, \mathrm{CC}, 1-4$ & 48 & & 1 & 9 & & 29 & 6 & 0.5 & & & & & & 6.5 & & 20 & \\
\hline $11-1,75-79$ & & & & & & + & * & & & & & & & & 100 & 0.3 & \\
\hline $11-2,78-82$ & & & & & & & & * & & & & & & * & 100 & 0.9 & \\
\hline $11-3,75-79$ & * & & & & & * & & ++ & & & & & & * & 100 & 1.5 & \\
\hline $11-4,76-80$ & & & & & & & & •* & & & & & & - & 100 & 0.4 & \\
\hline $11-5,75-79$ & 55.2 & & & & 0.7 & 13.4 & 13.4 & & & & & & & 17.2 & 97.8 & 7.4 & \\
\hline $11-6,75-79$ & & & & * & & & & + & & & * & & & * & 88.9 & 0.3 & \\
\hline $11-7,31-35$ & & & & & & & & + & & & + & & & 0 & 100 & 0.3 & \\
\hline $11, \mathrm{CC}, 30-34$ & & & & & & & & ++ & & & + & & & 0 & 82 & 1.6 & \\
\hline $12-1,74-78$ & & & & & & & & ++ & & & + & & & * & 100 & 0.9 & \\
\hline $12-2,74-78$ & & & & & & & & + & & & + & & & 0 & 64 & 0.8 & \\
\hline $12-3,74-78$ & & & & & & & & ++ & & & & & & * & 100 & 0.3 & $\mathrm{Cl}$ \\
\hline $12-4,74-78$ & & & & & & & & + & & & + & & & 0 & 92 & 0.7 & \\
\hline $12-5,74-78$ & & & & & & & & & & & + & & & 0 & 67 & 0.1 & \\
\hline $12-6,74-78$ & & & & & & & & + & & & ++ & & & 0 & 73 & 0.9 & \\
\hline $13-1,73-77$ & & & & & & & & + & & & & & & 0 & 100 & 0.1 & \\
\hline $13-2,73-77$ & & & & & & & & $\cdot$ & & & + & & & 0 & 100 & 0.6 & \\
\hline $13-3,73-77$ & & & & & & & & + & & & & & & 0 & 100 & 0.3 & \\
\hline $13-4,73-77$ & & & & & & & & ++ & & & * & & & 0 & 100 & 2.8 & \\
\hline $13-5,73-77$ & & & & & & & & + & & & & & & 0 & 100 & 0.1 & \\
\hline $13-6,73-77$ & & & & & & & & ++ & & & + & & & 0 & 74 & 0.9 & \\
\hline $13, \mathrm{CC}, 13-17$ & & & Barren & & & & & & & & & & & & & & \\
\hline $14-1,74-78$ & & & & & & & * & ++ & & & & & & * & 94 & 0.8 & \\
\hline $14-2,74-78$ & & & & & & & & & & & * & & & 0 & 100 & 0.06 & \\
\hline $14-3,74-78$ & & & & & & & & + & & & * & & & - & 82 & 0.8 & \\
\hline $14-4,74-78$ & & & Barren & & & & & & & & & & & & & & \\
\hline $14-5,74-78$ & & & & & & & & ++ & & & & & & 0 & 83 & 0.6 & \\
\hline $14-6,74-78$ & & & & & & & & & & & & & & - & 100 & 0.06 & \\
\hline $14, \mathrm{CC}, 20-24$ & & & & & & & & ++ & & & + & & & 0 & 100 & 0.8 & \\
\hline $15-1,75-79$ & & & Barren & & & & & & & & & & & & & & \\
\hline $15-2,75-79$ & & & & & & & & + & & & * & & & 0 & 35 & 0.4 & \\
\hline $15-3,75-79$ & & & & & & & & & & & * & & & ++ & 100 & 0.2 & \\
\hline $15-4,75-79$ & & & & & & & & ++ & & & & & & 0 & 100 & 0.4 & \\
\hline $15-5,75-79$ & & & & & & & & & & & + & & & 0 & 100 & 0.06 & \\
\hline $15-6,75-79$ & & & & & & ++ & & + & & & + & & & ++ & 93.9 & 1.7 & $\mathrm{C} 2$ \\
\hline $15, \mathrm{CC}, 12-16$ & & & & & & & & & & & + & & & 0 & 100 & 0.06 & \\
\hline $16-1,73-77$ & & & & & & & & * & & & & & & 0 & 75 & 0.4 & \\
\hline $16-2,73-77$ & & & & & & & & * & & & & & & * & 100 & 0.1 & \\
\hline $16-3,73-77$ & & & 15 & 39.6 & & 2.8 & & 8.5 & & & 5.6 & & & 28.3 & 57.6 & 6 & \\
\hline $16-4,73-77$ & & & & & & & * & & & & * & & & * & 100 & 0.2 & \\
\hline $16-5,73-77$ & & & Barren & & & & & & & & & & & & & & \\
\hline $16-6,73-77$ & & & & & & & & & & & & & & * & 100 & 0.06 & \\
\hline 16, CC, $38-42$ & & & & & & & & ++ & & & * & & & + & 50 & 1.1 & \\
\hline $17-1,60-64$ & & & * & & & & & * & & & & & & 0 & 100 & 0.06 & \\
\hline $18-1,73-77$ & & & & & & & & ++ & & & + & & & 0 & 88 & 0.8 & \\
\hline $18-2,73-77$ & & & & & & & & + & & & & & & 0 & 100 & 0.1 & \\
\hline $18, \mathrm{CC}, 18-22$ & & & & & & & & + & & & * & & & 0 & 100 & 0.3 & \\
\hline $19-1,74-78$ & & & & & & & & & & & * & & & 0 & 100 & 0.1 & \\
\hline $19-2,74-78$ & & & Barren & & & & & & & & & & & & & & \\
\hline
\end{tabular}


Table 5 (continued)

\begin{tabular}{|c|c|c|c|c|c|c|c|c|c|c|c|c|c|c|c|c|c|}
\hline Sample (cm) & E. umbo & C. wuell & C. subgl & E. exigua & C. laevig & M. zaand & Cib spp & Spiroloc & Trocham & Tubes & Spirosi & Haploph & Cyclam & Other & $\% \mathrm{BF}$ & No. $/ \mathrm{cm}^{3}$ & Zones \\
\hline $19-3,74-78$ & & & Barren & & & & & & & & & & & & & & \\
\hline $19-4,74-78$ & & & & & & & & & & & * & & & 0 & 100 & 0.2 & \\
\hline $19-5,74-78$ & & & Barren & & & & & & & & & & & & & & \\
\hline $\begin{array}{l}19-6,74-78 \\
19, \text { СС, } 10-14\end{array}$ & & & Barren & & & & & + & & & & & & 0 & 100 & 0.9 & \\
\hline $20-1,74-78$ & & & & & & & & * & & & + & & & 0 & 100 & 0.9 & \\
\hline $20-2,74-78$ & & & & & & & & & & & + & & & 0 & 100 & 0.3 & \\
\hline $20-3,74-78$ & & & & & & & & * & & & & & & 0 & 100 & 0.2 & \\
\hline $20-4,74-78$ & & & Barren & & & & & & & & & & & & & & \\
\hline $20-5,74-78$ & & & & & & & & * & & & * & & & 0 & 100 & 0.2 & \\
\hline $20-6,74-78$ & & & & & & & & & & & + & & & 0 & 100 & 0.2 & \\
\hline $20-7,5-9$ & & & & & & & & * & & & $*$ & & & 0 & 72 & 1.3 & \\
\hline $20, \mathrm{CC}, 15-19$ & & & & & & & & & & & + & & & 0 & 100 & 0.25 & \\
\hline $21, \mathrm{CC}, 0-4$ & & & & & & & & * & & & * & & & 0 & 100 & 0.2 & \\
\hline $22-1,74-78$ & & & & & & & & & & & * & & & 0 & 100 & 0.1 & \\
\hline $22-2,74-78$ & & & & & & & & +++ & & & * & & & 0 & 83 & 1.6 & \\
\hline $22-3,74-78$ & & & Barren & & & & & & & & & & & & & & \\
\hline $22-4,74-78$ & & & & & & & & ++ & & & & & & 0 & 100 & 0.5 & \\
\hline $22-5,74-78$ & & & Barren & & & & & & & & & & & & & & \\
\hline $22-6,74-78$ & & & & & & & & + & & & & & & 0 & 63 & 0.3 & \\
\hline $22, \mathrm{CC}, 22-26$ & & & & & & & & & & & * & & & $*$ & 100 & 0.2 & \\
\hline $23-1,78-82$ & & & & & & & & ++ & & & & & & 0 & 70 & 0.4 & \\
\hline $23-2,78-82$ & & & & & & & & $*$ & & & & & & * & 100 & 0.1 & \\
\hline $23-3,78-82$ & & & & & & & & ++ & & & & & & 0 & 70 & 0.4 & \\
\hline $23-4,78-82$ & & & Barren & & & & & & & & & & & & & & \\
\hline $23-5,78-82$ & & & & & & & & * & & & ++ & & & * & 58 & 0.6 & \\
\hline $23-6,78-82$ & & & & & & & & & & & $*$ & & & 0 & 100 & 0.06 & \\
\hline $23, \mathrm{CC}, 18-22$ & & & & & & & & & & & + & & & * & 71 & 0.2 & \\
\hline $24-1,75-79$ & & & Barren & & & & & & & & & & & & & & \\
\hline $24-2,75-79$ & & & & & & & & * & & & * & & & 0 & 40 & 0.1 & \\
\hline $24-4,75-79$ & & & & & & & & ++ & & & * & & & 0 & 63 & 2.2 & \\
\hline $24-5,75-79$ & & & Barren & & & & & & & & & & & & & & \\
\hline 24-6, 75-79 & & & & & & & & * & & & ++ & & & 0 & 63 & 0.7 & $\mathrm{C} 2$ \\
\hline $24, C C, 22-26$ & & & Barren & & & & & & & & 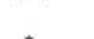 & & & & & & \\
\hline $25-1,75-79$ & & & Barren & & & & & & & & * & & & 0 & 100 & 0.06 & \\
\hline $25-2,75-79$ & & & & & & & & & & & & & & & & & \\
\hline $25-3,75-79$ & & & $\begin{array}{l}\text { Barren } \\
\text { Barren }\end{array}$ & & & & & & & & & & & & & & \\
\hline $25-4,75-79$ & & & & & & & & & & & & & & & & & \\
\hline $25-5,75-79$ & & & Barren & & & & & & & & & & & & & & \\
\hline $25-6,75-79$ & & & Barren & & & & & & & & & & & & & & \\
\hline $25, \mathrm{CC}, 21-25$ & & & & & & & & * & & & & & & 0 & 100 & 0.06 & \\
\hline $26-1,75-79$ & & & Barren & & & & & & & & & & & & & & \\
\hline $26-2,75-79$ & & & & & & & & & & & * & & & 0 & 100 & 0.06 & \\
\hline $26-3,75-79$ & & & Barren & & & & & & & & & & & & & & \\
\hline $26-4,75-79$ & & & & & & & & $*$ & & & & & & 0 & 100 & 0.1 & \\
\hline $26-5,75-79$ & & & Barren & & & & & & & & & & & & & & \\
\hline $26-6,75-79$ & & & Porren & & & & & * & & & & & & 0 & 100 & 0.1 & \\
\hline 26, CC, $25-29$ & & & Barren & & & & & * & & & & & & 0 & 100 & 01 & \\
\hline $27-2,75-79$ & & & Barren & & & & & & & & & & & & 100 & 0.1 & \\
\hline $27-3,75-79$ & & & Barren & & & & & & & & & & & & & & \\
\hline $27-4,75-79$ & & & Barren & & & & & & & & & & & & & & \\
\hline $27-5,75-79$ & & & & & & & & & & & + & & & 0 & 100 & 0.06 & \\
\hline $27-6,75-79$ & & & & & & & & & & & * & & & - & 100 & 0.2 & \\
\hline $27, \mathrm{CC}, 75-79$ & & & & & & & & * & & & & & & 0 & 100 & 0.06 & \\
\hline $28-1,74-78$ & & & & & & & & & & & * & & & 0 & 100 & 0.1 & \\
\hline $28-2,74-78$ & & & & & & & & * & & & * & & & 0 & 100 & 0.4 & \\
\hline $28-3,74-78$ & & & Barren & & & & & & & & & & & & & & \\
\hline $28-4,74-78$ & & & Barren & & & & & & & & & & & & & & \\
\hline $28-5,74-78$ & & & & & & & & & & & * & & & 0 & 100 & 0.06 & \\
\hline
\end{tabular}




\begin{tabular}{|c|c|c|c|c|c|c|c|c|c|c|c|c|c|c|c|c|c|}
\hline Sample (cm) & E. umbo & C. wuell & C. subgl & E. exigua & C. laevig & M. zaand & Cib spp & Spiroloc & Trocham & Tubes & Spirosi & Haploph & Cyclam & Other & $\% \mathrm{BF}$ & No. $/ \mathrm{cm}^{3}$ & Zones \\
\hline $\begin{array}{l}28-6,74-78 \\
28, C C, 30-34\end{array}$ & & & Barren & & & & & * & & & & & & 0 & 100 & 0.1 & \\
\hline $29-1,75-79$ & & & & & & & & $*$ & & & & & & 0 & 100 & 0.06 & \\
\hline $29-2,74-79$ & & & Barren & & & & & & & & & & & & & & \\
\hline $29-3,75-79$ & & & & & & & & ++ & & & * & & & 0 & 67 & 0.2 & \\
\hline $29-4,74-79$ & & & Barren & & & & & & & & & & & & & & \\
\hline $29-5,75-79$ & & & & & & & & ++ & & & & & & 0 & 40 & 0.3 & \\
\hline $29-6,75-79$ & & & & & & & & & & & - & & & 0 & 100 & 0.06 & \\
\hline 29, CC, $11-15$ & & & 49.6 & & 1.3 & 2 & 5.4 & 0.6 & & & 2.7 & & & 39.4 & 84 & 8.2 & \\
\hline $30, \mathrm{CC}, 46-48$ & & & Barren & & & & & & & & & & & & & & \\
\hline $31-1,74-78$ & & & Barren & & & & & & & & & & & & & & \\
\hline $31-2,74-78$ & & & Barren & & & & & & & & & & & & & & \\
\hline $31-3,74-78$ & & & Barren & & & & & & & & & & & & & & \\
\hline $31-4,74-78$ & & & Barren & & & & & & & & & & & & & & $\mathrm{C} 2$ \\
\hline $31-6,63-67$ & & & Barren & & & & & & & & & & & & & & \\
\hline $31, \mathrm{CC}, 26-30$ & & & & & & & & & & + & * & & & * & 100 & 0.2 & \\
\hline $32-1,74-78$ & & & Barren & & & & & & & & & & & & & & \\
\hline $32-2,74-78$ & & & Barren & & & & & & & & & & & & & & \\
\hline $32-3,74-78$ & & & & & & & & * & & & & & & - & 100 & 0.1 & \\
\hline $33-1,75-79$ & & & Barren & & & & & & & & & & & & & & \\
\hline $33-2,75-79$ & & & & & & & & * & & & & & & + & 100 & 0.3 & \\
\hline $33, \mathrm{CC}, 16-20$ & & & & & & & & & & & & & & * & 100 & 0.05 & \\
\hline $34-2,74-78$ & & & & & & & & & & & & & & + & 100 & 0.4 & \\
\hline $34, \mathrm{CC}, 20-24$ & & & & & & & & & & * & & & & 0 & 100 & 0.2 & \\
\hline $35-1,71-74$ & & & Barren & & & & & & & & & & & & & & \\
\hline $35, \mathrm{CC}, 18-22$ & & & & & & & & & & + & & & & 0 & 100 & 0.3 & \\
\hline $36-1,80-84$ & & & & & & & & & & + & & $*$ & & 0 & 100 & & \\
\hline $36-2,80-84$ & & & & & & & & & & * & & & * & 0 & 100 & 0.2 & \\
\hline $36-3,80-84$ & & & & & & & & & & ++ & & * & * & * & 100 & & \\
\hline $36-4,80-84$ & & & & & & & & & & & & & & * & 100 & 0.06 & \\
\hline $36-5,80-84$ & & & & & & & & + & & ++ & & + & + & * & 100 & & \\
\hline $36-6,80-84$ & & & Barren & & & & & & & & & * & & & & & \\
\hline $36, \mathrm{CC}, 12-16$ & & & & & & & & & & * & & * & & * & 100 & & \\
\hline $37-2,69-72$ & & & & & & & & & & & & & & * & 100 & 0.1 & \\
\hline $37-3,69-72$ & & & & & & & & & & + & & * & & * & 100 & & \\
\hline $37-4,69-72$ & & & & & & & & & & & & & & * & 100 & 0.2 & \\
\hline $37, \mathrm{CC}, 26-29$ & & & & & & & & & & + & & * & * & * & 100 & & \\
\hline $38-1,76-79$ & & & Barren & & & & & & & & & & & & & & \\
\hline$* * 38-2,76-79$ & & & & & & & & & & ++ & & + & & * & & & \\
\hline $38, \mathrm{CC}, 23-26$ & & & & & & & & & & & & & & * & 100 & 0.2 & \\
\hline $39-1,95-99$ & & & & & & & & + & & & + & * & & + & 100 & & \\
\hline $39-2,95-99$ & & & Barren & & & & & & & & & & & & & & \\
\hline $39, \mathrm{CC}, 24-27$ & & & Barren & & & & & & & & & & & & & & \\
\hline $40, \mathrm{CC}, 18-21$ & & & Barren & & & & & & & & & & & & & & \\
\hline$* 42-2,78-82$ & & & & & & & & & & & & & & & & & $D$ \\
\hline $42-3,78-82$ & & & & & & & & & & & * & * & $*$ & * & 100 & 0.4 & D \\
\hline $43, \mathrm{CC}, 7-11$ & & & Barren & & & & & & & & & & & & & & \\
\hline $44-1,75-79$ & & & & & & & & & - & & & & & * & 100 & 0.2 & \\
\hline $44-2,75-79$ & & & & & & & & 7 & & 30 & 7 & 12 & 7 & 37 & & & \\
\hline $44-3,75-79$ & & & & & & & & & + & + & * & & & 0 & 100 & 0.4 & \\
\hline $44-4,75-79$ & & & & & & & & 1 & & 32 & 16 & 21 & & 30 & 100 & & \\
\hline $44-5,75-79$ & & & & & & & & 45.8 & 22 & 10.2 & 6.8 & 4.2 & 3.4 & 8.5 & 100 & 6.6 & \\
\hline $44-6,75-79$ & & & & & & & & 25 & & 13 & 18 & 7 & 2 & 35 & 100 & & \\
\hline $44, \mathrm{CC}, 10-14$ & & & & & & & & & +++ & ++ & + & * & ++ & ++ & 100 & 2 & \\
\hline $45-1,74-78$ & & & & & & & & * & * & + & * & • & $*$ & ++ & 100 & & \\
\hline $45-2,74-78$ & & & & & & & & 8.2 & 20.9 & 24.6 & 8.5 & 8.2 & 5.5 & 16.4 & 100 & 6.1 & \\
\hline $45-3,74-78$ & & & & & & & & 27 & 3 & 24 & 10 & 8 & 6 & 22 & & & \\
\hline $45-4,74-78$ & & & & & & & & 24.7 & 8.2 & 24 & 17.8 & 1.4 & 13 & 9.6 & 100 & 9.1 & \\
\hline $45-5,74-78$ & & & & & & & & 14 & 1 & 26 & 6 & 16 & 3 & 34 & & & \\
\hline
\end{tabular}


Table 5 (continued).

\begin{tabular}{|c|c|c|c|c|c|c|c|c|c|c|c|c|c|c|c|c|c|}
\hline Sample $(\mathrm{cm})$ & E. umbo & C. wuell & C. subgl & E. exigua & C. laevig & M. zaand & Cib spp & Spiroloc & Trocham & Tubes & Spirosi & Haploph & Cyclam & Other & $\% \mathrm{BF}$ & No. $/ \mathrm{cm}^{3}$ & Zones \\
\hline $45-6,74-78$ & & & & & & & & & + & * & + & & $*$ & ++ & 100 & 1.1 & \\
\hline 45, CC, $10-14$ & & & & & & & & 16 & 1 & 22 & 1 & 2 & 4 & 54 & & & \\
\hline $46-1,75-78$ & & & & & & & & 1.1 & 6.5 & 23.9 & 8.7 & 2.2 & 37 & 19.6 & 100 & 5.1 & \\
\hline $46-2,75-78$ & & & & & & & & 7 & & 17 & 12 & 24 & 7 & 33 & 100 & & \\
\hline $46-3,75-78$ & & & & 0.5 & & & & 25.9 & 6.4 & 19.6 & 4.2 & 8.5 & 16.4 & 14.3 & 100 & 10.5 & \\
\hline $46-4,75-78$ & & & & 0.0 & & & & 12 & 4 & 23 & 2 & 5 & 5 & 49 & 100 & 10.0 & \\
\hline $46-5,75-78$ & & & & & & & & 1.9 & 5.8 & 29.9 & 3.9 & 5.2 & 36.4 & 18.2 & 100 & 8.6 & \\
\hline \multicolumn{18}{|l|}{$* * 46-6,75-78$} \\
\hline 46, CC, $13-17$ & & & & & & 3.6 & & 3.6 & 11.9 & 23.8 & 10.7 & 13.1 & 21.4 & 11.9 & 100 & 4.9 & \\
\hline $47-1,75-79$ & & & & & & & & 5 & 4 & 20 & & 7 & 7 & 57 & 100 & & \\
\hline $47-2,75-79$ & & & & & & & & 0.6 & 3.6 & 50 & 0.6 & 11.9 & 24.9 & 8.9 & 100 & 18.7 & \\
\hline $47-3,75-79$ & & & & & & & & 2 & & 29 & & 12 & & 57 & & & \\
\hline $47-4,75-79$ & & & & & & & & & 4.2 & 22.2 & & 13 & 31.8 & 28.9 & 100 & 13.3 & \\
\hline $47-5,75-79$ & & & & & & & & & & 28 & & 34 & & 38 & 100 & & \\
\hline $47-6,75-79$ & & & & & & & & & * & +++ & & + & + & $*$ & 100 & 3.9 & \\
\hline $47, C C, 21-25$ & & & & & & & & 1 & 3 & 19 & & 24 & 3 & 50 & & & \\
\hline $48-1,75-79$ & & & & & & & & & 4.5 & 46.9 & 4.5 & 25.2 & 8.1 & 10.8 & 100 & 6.2 & \\
\hline $48-2,75-79$ & & & & & & & & 1 & 2 & 15 & & 16 & 1 & 65 & & & \\
\hline $48-3,75-79$ & & & & & & & & 3.5 & 1.2 & 48.8 & 2.3 & 10.5 & 19.8 & 14.9 & 100 & 4.8 & \\
\hline $48-4,75-79$ & & & & & & & & & & 7 & & 25 & 4 & 64 & & & \\
\hline $48-5,75-79$ & & & & & & & & 2.2 & 1.1 & 27.8 & 1.1 & 24.4 & 41.1 & 2.3 & 100 & 5.3 & \\
\hline $48-6,75-79$ & & & & & & & & & & 34 & & 9 & 18 & 39 & & & \\
\hline $48, \mathrm{CC}, 18-22$ & & & & & & & & & & 76.3 & & & 17.5 & 6.2 & 100 & 4.4 & \\
\hline $49-1,75-79$ & & & & & & & & & & & & & & & & & \\
\hline $49-2,75-79$ & & & & & & & & * & & & * & & * & * & 100 & 0.5 & \\
\hline \multicolumn{18}{|l|}{$49-3,75-79$} \\
\hline $49-4,75-79$ & & & & & & & & 1 & 1 & 41.3 & & 16.3 & 33.3 & 7.1 & 100 & 5.8 & \\
\hline $49-5,75-79$ & & & & & & & & 2 & & 24 & & 22 & 13 & 39 & & & \\
\hline $49-6,75-79$ & & & & & & & & 3.4 & & 14.8 & 1.1 & & 35.2 & 10.2 & 100 & 5.2 & \\
\hline 49, CC, $11-14$ & & & & & & & & 2 & 2 & 33 & & 31 & 21 & 11 & & & \\
\hline $50-1,2-4$ & & & & & & & & & & & & & & ${ }^{*}$ & 100 & 0.2 & \\
\hline $50, \mathrm{CC}, 20-24$ & & & & & & & & 1 & 1 & 32 & & 43 & 9 & 14 & D & & \\
\hline $51-1,75-79$ & & & & & & & & & 1 & 17.9 & & 67.4 & 7.4 & 6.3 & 100 & 10.6 & \\
\hline $51-2,75-79$ & & & & & & & & & & 16 & & 78 & & 6 & & & \\
\hline $51-3,75-79$ & & & & & & & & & & * & & & & 0 & 100 & 0.2 & \\
\hline $51-4,75-79$ & & & & & & & & & & ++ & & ++ & * & & 100 & & \\
\hline $51-5,75-79$ & & & & & & & & & & 82.6 & & 4.6 & 5.5 & 7.3 & 100 & 6.1 & \\
\hline $51-6,75-79$ & & & & & & & & & 1 & 38 & & 17 & 16 & 28 & 100 & & \\
\hline $51-6,115-117$ & & & & & & & & & $*$ & & & & & & 100 & 0.2 & \\
\hline $51, \mathrm{CC}, 33-37$ & & & & & & & & & 6 & 32 & 1 & 17 & 8 & 36 & 100 & & \\
\hline $52-1,80-84$ & & & & & & & & & & 34.1 & & & 57.7 & 8.2 & 100 & 6.8 & \\
\hline $52-2,80-84$ & & & & & & & & & 6 & 41 & & 7 & 2 & 44 & 100 & & \\
\hline $52-3,80-84$ & & & & & & & & & 1.3 & 44.3 & & 12.8 & 28.9 & 12.8 & 100 & 8.3 & \\
\hline $52-4,80-84$ & & & & & & & & & 2 & 59 & & 9 & 12 & 18 & & & \\
\hline $52-5,80-84$ & & & & & & & & & * & ++ & & * & ++ & $*$ & 100 & 2.7 & \\
\hline $52-6,80-84$ & & & & & & & & & & 29 & & 12 & 18 & 41 & & & \\
\hline $52, \mathrm{CC}, 18-22$ & & & & & & & & & & ++ & & $*$ & & $*$ & 100 & 3.3 & \\
\hline $53-1,75-78$ & & & & & & & & & & 44 & & 1 & 26 & 29 & & & \\
\hline $53-2,75-78$ & & & & & & & & & 5.7 & 32 & & 5.7 & 43.4 & 13.1 & 100 & 6.8 & \\
\hline $53-3,75-78$ & & & & & & & & & 7 & 48 & & 7 & 10 & 28 & & & \\
\hline $53-4,75-78$ & & & & & & & & & 4 & 58 & & 8.3 & 23 & 6.7 & 100 & 41.3 & \\
\hline $53-5,75-78$ & & & & & & & & & 1 & 71 & & 5 & 7 & 16 & & & \\
\hline $53-6,75-78$ & & & & & & & & & & 82.8 & & 5.3 & & 11.9 & 100 & 12.6 & \\
\hline $53, \mathrm{CC}, 10-13$ & & & & & & & & & 5 & 74 & & 1 & 5 & 15 & & & \\
\hline $54-1,72-76$ & & & & & & & & & 2.6 & 88 & & 4.9 & & 5.2 & 100 & 14.8 & \\
\hline $54-2,72-76$ & & & & & & & & & & 68 & & 9 & & 23 & & & \\
\hline $54-3,72-76$ & & & & & & & & & & * & & & & 0 & 100 & 0.2 & \\
\hline $54-4,72-76$ & & & & & & & & & & + & & - & & * & & & \\
\hline $54-5,72-76$ & & & & & & & & & & * & & & & 0 & 100 & 0.2 & \\
\hline
\end{tabular}


Table 5 (continued).

\begin{tabular}{|c|c|c|c|c|c|c|c|c|c|c|c|c|c|c|c|c|c|}
\hline Sample $(\mathrm{cm})$ & E. umbo & C. wuell & C. subgl & E. exigua & C. laevig & M. zaand & Cib spp & Spiroloc & Trocham & Tubes & Spirosi & Haploph & Cyclam & Other & $\% \mathrm{BF}$ & No. $/ \mathrm{cm}^{3}$ & Zones \\
\hline $54-6,72-76$ & & & & & & & & & * & ++ & & & & ++ & & & \\
\hline $54, \mathrm{CC}, 71-21$ & & & & & & & & & 2 & 86.3 & & 4.4 & & 7.2 & 100 & 13.8 & E \\
\hline $55-1,75-79$ & & & & & & & & & 11 & 49 & & 1 & 4 & 35 & & & \\
\hline $55-2,75-79$ & & & & & & & & 0.7 & 6.6 & 56.6 & & 13.2 & & 22.9 & 100 & 7.6 & \\
\hline $55-3,75-79$ & & & Barren & & & & & & & & & & & & & & \\
\hline $55-4,75-79$ & & & & & & & & & 8 & 70.1 & & & & 21.7 & 100 & 4.8 & \\
\hline $55-5,75-79$ & & & & & & & & & * & + & & - & & & & & \\
\hline $55-6,75-79$ & & & & & & & & & 4 & 84.2 & & 1.1 & 2.6 & 8.1 & 100 & 15.1 & \\
\hline $56-1,74-78$ & & & & & & & & & & & & * & * & +++ & 100 & 1.4 & \\
\hline $56-2,74-78$ & & & & & & & & & + & ++ & & & & ++ & & & \\
\hline $56-3,74-78$ & & & Barren & & & & & & & & & & & 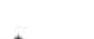 & & & \\
\hline $56-4,74-78$ & & & & & & & & & - & + & & & & * & & & \\
\hline $56-5,74-78$ & & & & & & & & & & +++ & & & * & * & & 2.7 & E \\
\hline $56-6,74-78$ & & & & & & & & & * & ++ & & • & & ++ & & & \\
\hline $56, \mathrm{CC}, 6-10$ & & & & & & & & & & +++ & & & & 0 & & 2.7 & \\
\hline $57-1,75-78$ & & & & & & & & & * & ++ & & & & + & & & \\
\hline $57-2,75-78$ & & & & & & & & & & 97.6 & & 0.6 & & 1.5 & 100 & 36.6 & \\
\hline $57-3,75-78$ & & & & & & & & & * & ++ & & * & * & + & & & \\
\hline $57-4,75-78$ & & & & & & & & & & +++ & & * & & * & 100 & 3.7 & \\
\hline $57-5,75-78$ & & & & & & & & & * & ++ & & - & & + & & & \\
\hline $57-6,75-78$ & & & & & & & & & & $*$ & & & $*$ & 0 & 100 & 0.3 & \\
\hline $57, \mathrm{CC}, 20-23$ & & & Barren & & & & & & & & & & & & & & \\
\hline $59-1,75-78$ & & & Barren & & & & & & & & & & & & & & \\
\hline $59, \mathrm{CC}, 20-23$ & & & Barren & & & & & & & & & & & & & & \\
\hline $60-1,94-97$ & & & Barren & & & & & & & & & & & & & & Barren \\
\hline $60-2,94-97$ & & & Barren & & & & & & & & & & & & & & \\
\hline $61-1,75-78$ & & & Barren & & & & & & & & & & & & & & \\
\hline $62-1,75-78$ & & & Barren & & & & & & & & & & & & & & \\
\hline
\end{tabular}

*Species: $E$. umbo $=$ Oridorsalis umbonatus; $C$. wuell $=$ Cibicides wuellerstorfi $;$. subgl $=$ Cassidulina subglobosa E. exigua $=$ Epistominella exigua $;$ C. laevig $=$ Cassidulina laevigata $;$. zaand $=$ Melonis zaandami; Cib spp = Cibicides spp.; Spiroloc $=$ Spirolocammina sp.; Trocham $=$ Trochammina spp.; Spirosi $=$ Spirosigmoilinella sp.; Haploph $=$ Haplophragmoides spp.; Cyclam $=$ Cyclammina spp. ${ }^{* *}$ These three samples contain shallow water calcareous foraminifers that are not included in these results. 


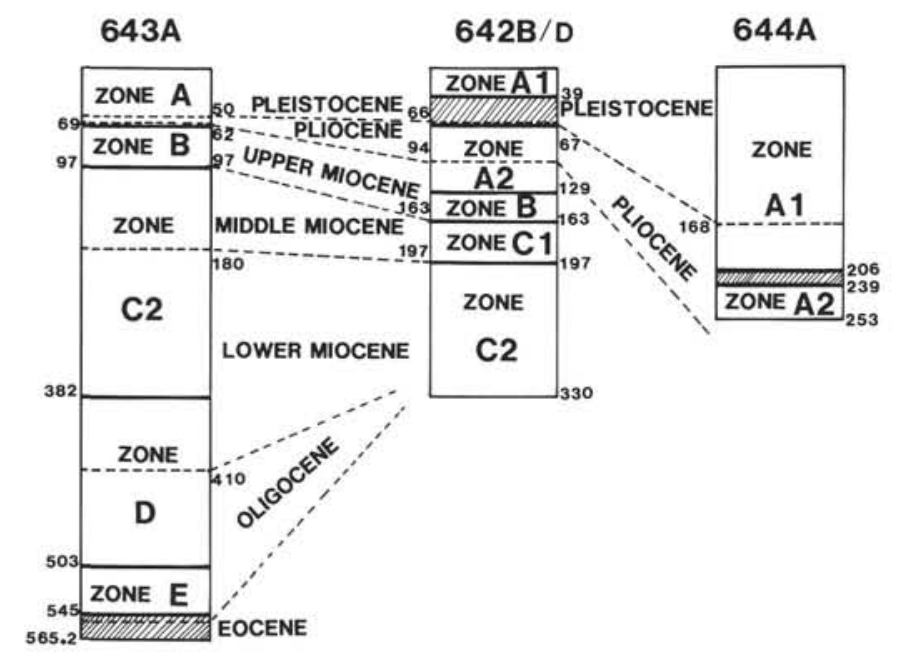

Figure 2. Benthic foraminifer zonation of (from left) Hole 643A, Hole $642 \mathrm{~B}$, and Hole $644 \mathrm{~A}$, showing the paleoceanographic transect of the Vøring Plateau (see Fig. 1). Depths of the recognized benthic foraminifer zones (solid lines) and epoch boundaries (dashed lines) are given in meters below sea floor. The epoch boundaries are taken directly from the biostratigraphic synthesis (Goll, this volume). The only change we suggest is in the placement of the upper Eocene and upper Oligocene boundaries, which benthic foraminifer evidence suggests should be moved up in Zone D. Barren zones are shown as hatchered area of the cores. 

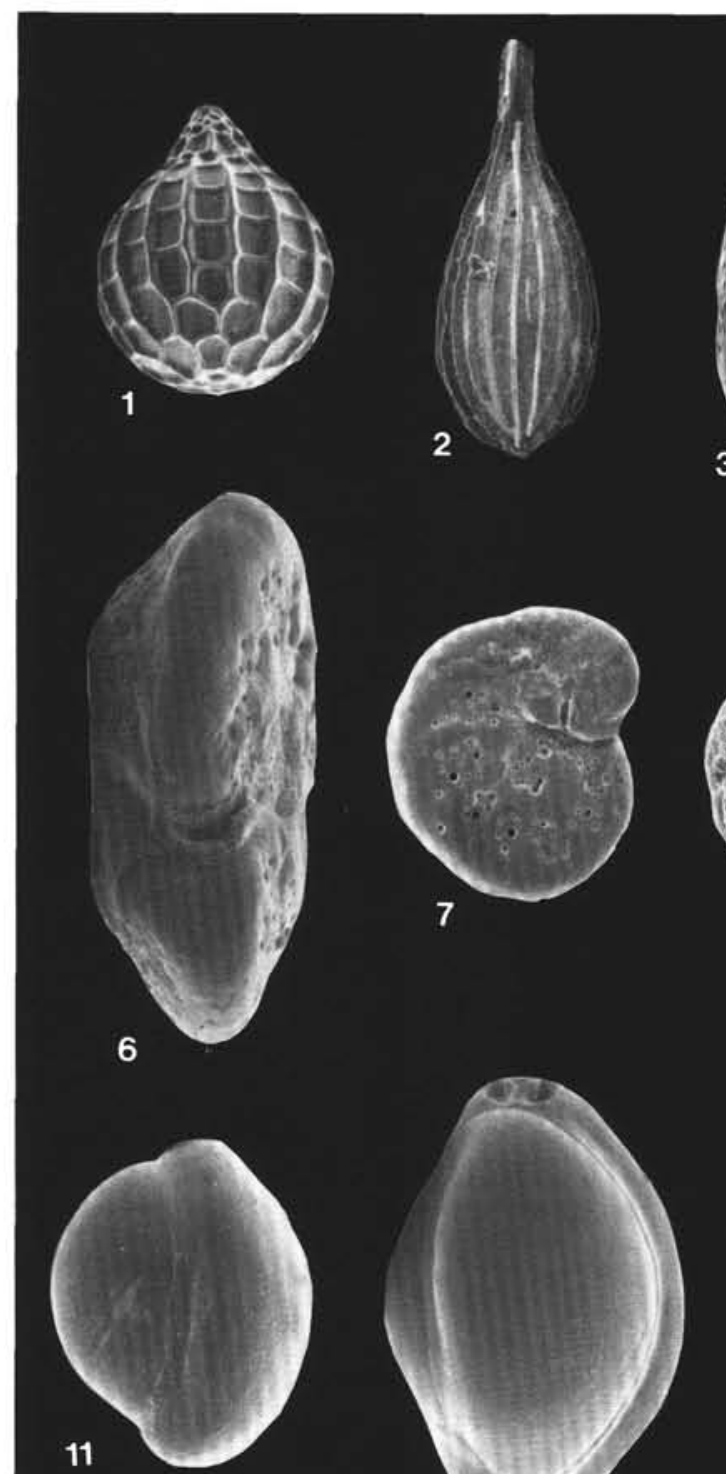

12
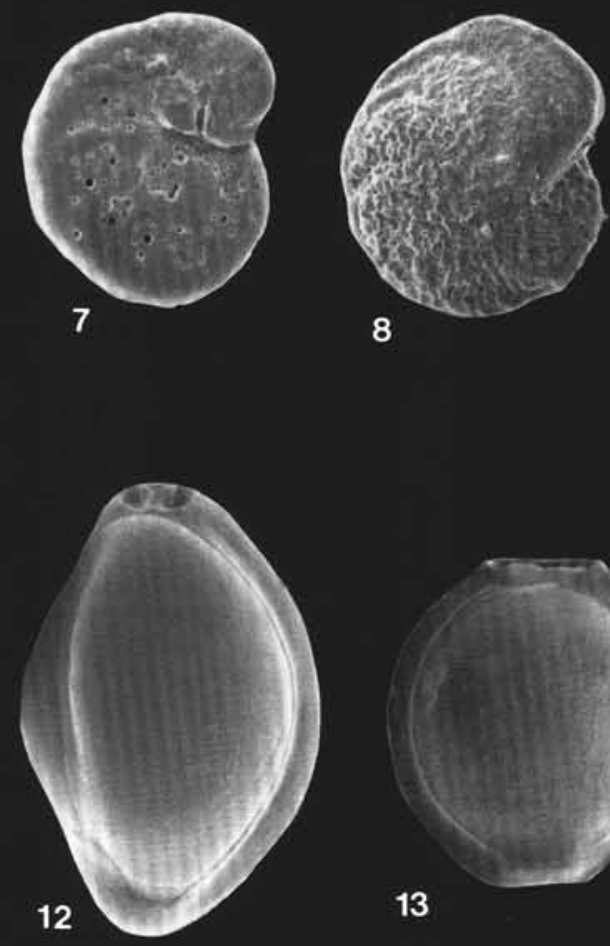

8

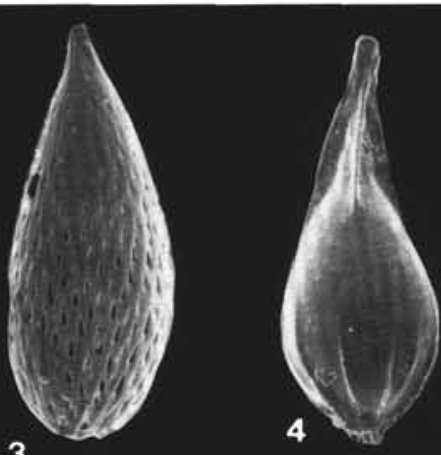

5
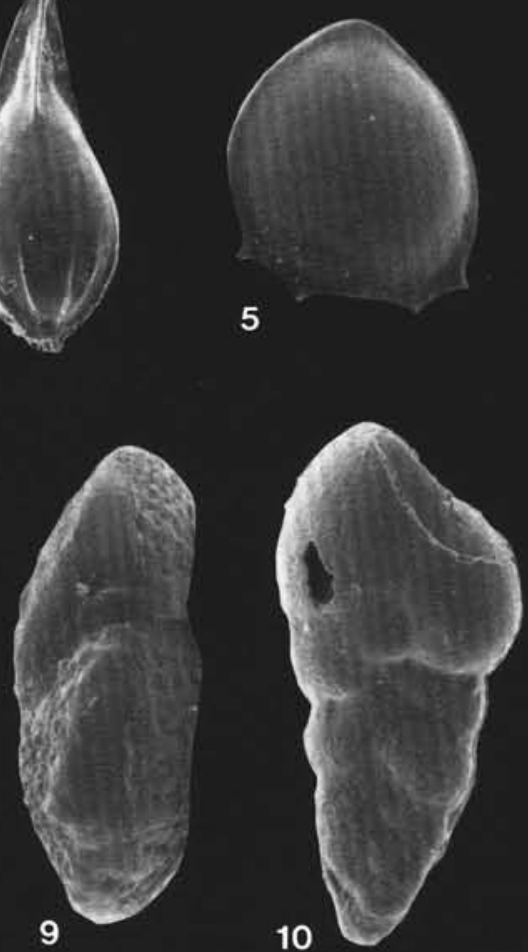

10

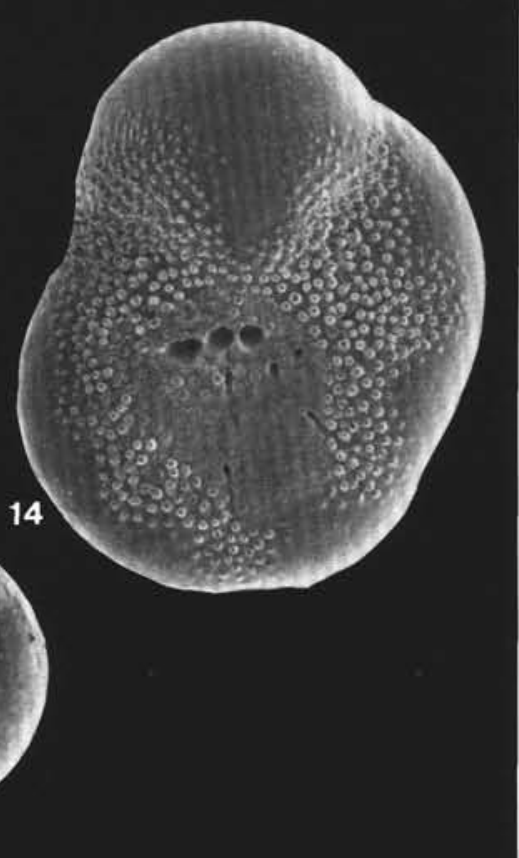

Plate 1. 1. Oolina melo d'Orbigny, 104-642B-2H-5, 36-40 cm $\times 145$. 2. Lagena sp., 104-642B-1H-3, $94-98 \mathrm{~cm} \times 127$ 3. Lagena sp., 104-642B1H-CC, 14-18 cm $\times 255$. 4. Lagena sp., 104-642B-1H-CC, 14-18 cm $\times 187$. 5. Fissurina sp., 104-642B-1H-3, 94-98 cm $\times 170$. 6. Cibicides lobatulus (Walker and Jacob), 104-642B-11H-3, 46-50 cm $\times 110$ (side view). 7. Cibicides lobatulus, 104-642B-11H-3, 46-50 cm $\times 59$. 8. Cibicides wuellerstorfi (Schwager), 104-642B-1H-CC, $14-18 \mathrm{~cm} \times 59$. 9. Cibicides wuellerstorfi, 104-642B-1H-CC, 14-18 cm $\times 93$ (side view). 10. Bolivina cf. cataniensis Seguenza, 104-642B-4H-6, 35-39 cm $\times 297$. 11. Pyrgo williamsoni (Silvestri), 104-642B-13H-4, 74-78 cm $\times 51$, side view. 12. Pyrgo williamsoni, 104-6428-13H-4, 74-78 $\mathrm{cm} \times 68$, sideview. 13. Pyrgo murrhina (Schwager), 104-643A-1H-2, 74-78 cm $\times 25$. 14. Buccella frigida (Cushman), 104-642A-1H-1, 94-98 cm $\times 255$. 15. Quinqueloculina sp., 104-642B-16H-5, 69-73 cm $\times 212$. 16. Quinqueloculina sp., 104$643 \mathrm{~A}-1 \mathrm{H}-2,74-78 \mathrm{~cm} \times 187$. 17. Triloculina trihedra Loeblich and Tappan, 104-642B-1H-3, 94-98 cm $\times 144$. 18. Gyroidina sp., 104-642B-3H-4, $36-40 \mathrm{~cm} \times 255$. 


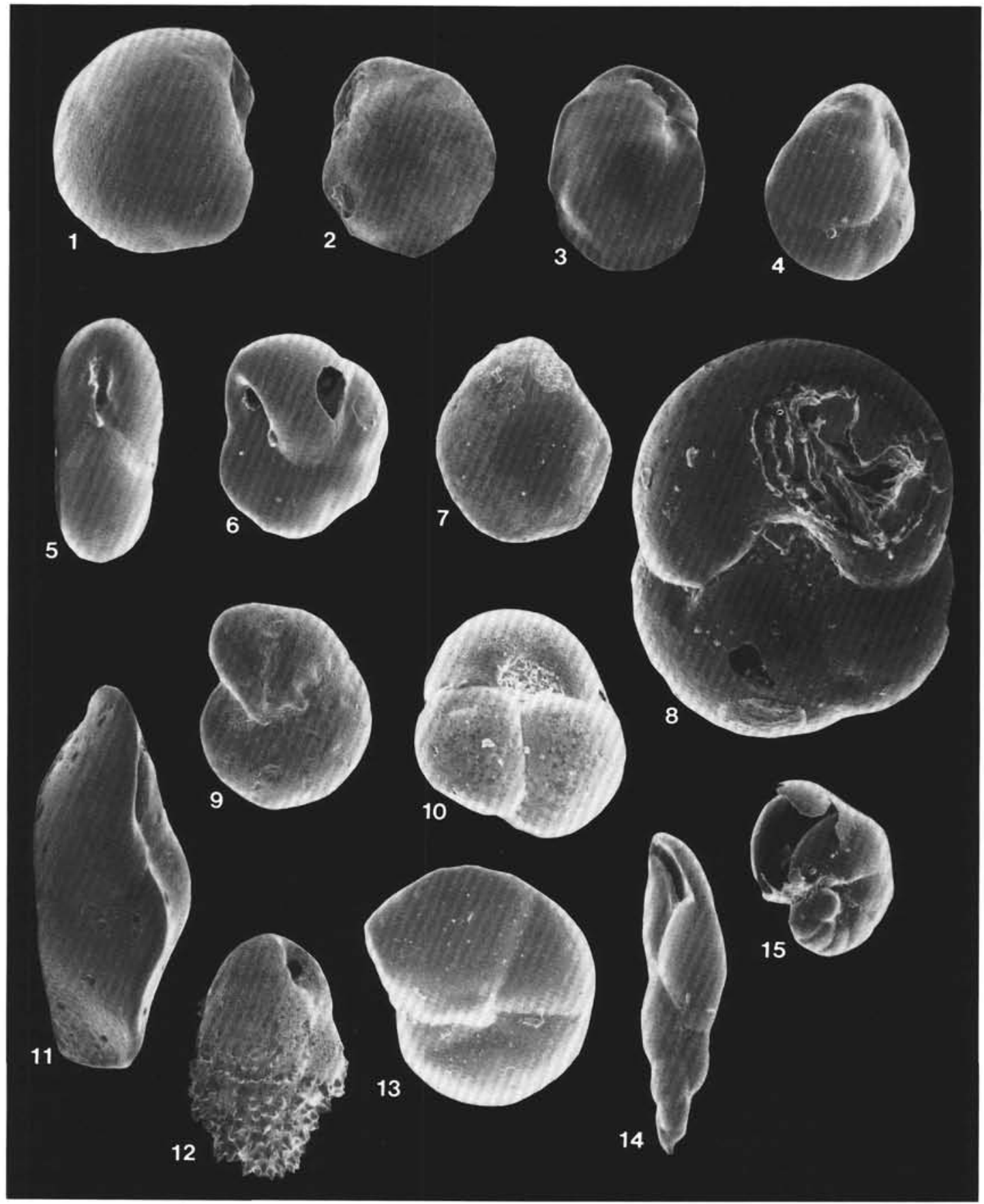

Plate 2. 1. Globocassidulina spherica Eade, 104-643A-3H-2, 74-78 cm $\times 51$. 2. Cassidulina laevigata d'Orbigny, 104-642B-11H-3, 46-50 cm $\times$ 127. 3. Cassidulina teretis Tappan, $104-642 \mathrm{~B}-11 \mathrm{H}-3,46-50 \mathrm{~cm} \times 85$. 4. Cassidulina reniforme Nørvang, $104-643 \mathrm{~A}-1 \mathrm{H}-1,117-119 \mathrm{~cm} \times 215$. 5. Epistominella exigua (Brady), 104-643A-11H-CC, 1-4 cm $\times 273$. 6. Epistominella exigua 104-643A-10H-3, 72-76 cm $\times 235$. 7. Epistominella exigua 104-642B-16H-5, 69-73 ×297. 8. Glabratella crassa Dorreen, 104-643A-2H-5, 76-78 cm $\times 393$, damaged specimen. 9. Elphidium excavatum (Terquem), 104-643A-1H-2, 74-78 cm $\times 85$. 10. Glabratella crassa 104-643A-2 H-5, 76-78 cm $\times 207$. 11. Cassidulina teretis Tappan, 104642B-11H-3, 46-50 cm $\times 170$ (side). 12. Bulimina marginata d'Orbigny, 104-642B-2H-5, 36-40 cm $\times 93$. 13. Stetsonia horvathi Green, 104-643A$1 \mathrm{H}-1,117-119 \mathrm{~cm} \times 280$. 14. Stanforthi loeblichi (Feyling-Hansen) 104-642B-1H-CC, 14-18, $\times 110$. 15. Nonionella sp. 104-642B-1H-CC, 14-18 $\mathrm{cm}$, damaged specimen, $\times 170$. 


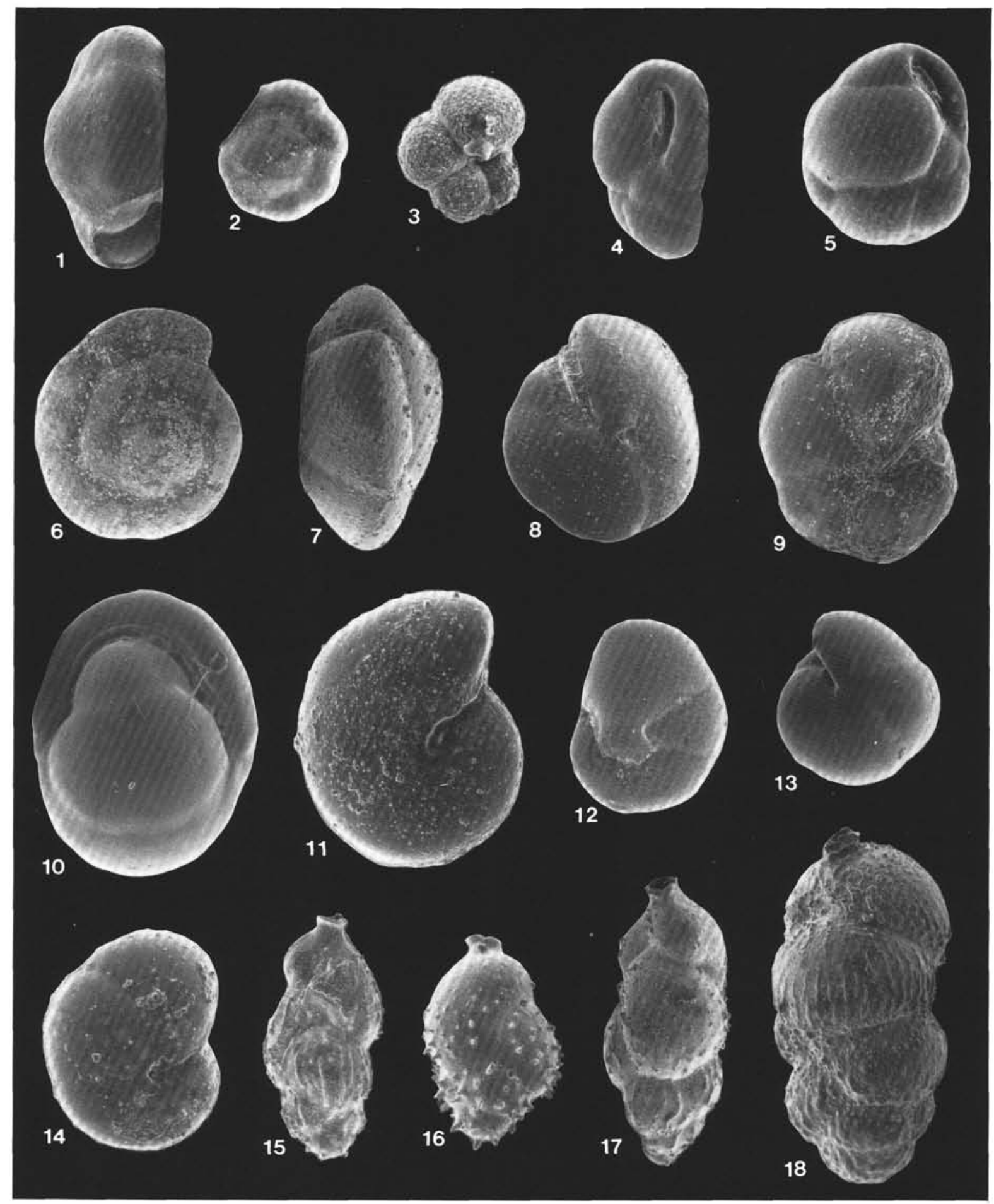

Plate 3. 1. Eponides tumidulis (Brady), 104-642B-1H-CC, $14-18 \mathrm{~cm} \times 297$. 2. Eponides tumidulis, 104-642B-1H-CC, 14-18 cm $\times 170$. 3. Neogloboquadrina padyderma (Ehrenberg), 104-642B-1H-CC, 14-18 cm $\times 187$. 4. Cassidulina subglubosa Brady, 104-642B-3H-4, 36-40 cm $\times 170$. 5. Cassidulina subglubosa, 104-642B-3H-4, 36-40 cm $\times 170$. 6. Oridorsalis umbonatus (Reuss), 104-642B-16H-7, 69-73 cm $\times 170$. 7. Oridorsalis umbonatus, 104-642B-16H-7, 69-73 cm $\times 212$ (side). 8. Oridorsalis umbonatus, 104-642B-16H-7, $69-73 \mathrm{~cm} \times 170$. 9. Pullenia quinqueloba (Reuss), 104-642B-16H-5, 69-73 cm $\times 212$. 10. Pullenia bulloides (d'Orgigny), 104-642B-15H-3, 74-78 cm $\times 170$ (side). 11. Melonis zaandami (van Voorthuysen), 104-642B-16H-5, 69-73 cm $\times 187$. 12. Valvulinina minuta 104-642B-15H-3, 74-78 cm $\times 127$. 13. Pullenia bulloides (d'Orbigny), 104-642B-15H-3, 74-78 cm $\times 110$. 14. Valvulina sp., 104-642B-16H-7, 69-73 cm $\times 255$. 15. Uvigerina pygmaea d'Orbigny, 104-642B17H-CC, 13-17 cm $\times 144$. 16. Uvigerina pygmaea, 104-642B-17H-CC, 13-17 cm $\times 187$. 17. Uvigerina pygmaea, 104-642B-17H-CC, 13-17 cm $\times 127$. 18. Uvigerina auberiana d'Orbigny, $104-643 \mathrm{~A}-7 \mathrm{H}-\mathrm{CC}, 9-12 \mathrm{~cm} \times 93$. 


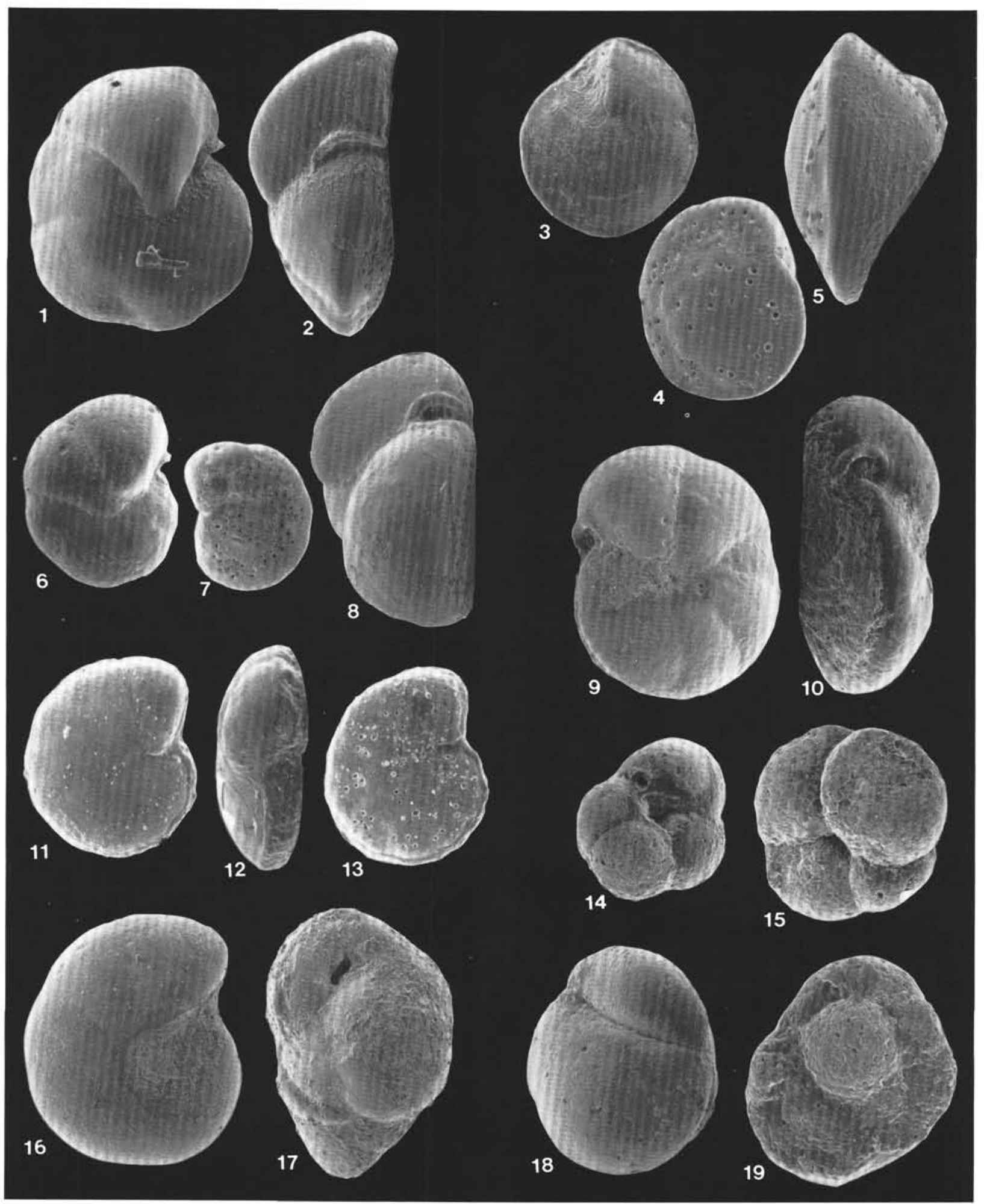

Plate 4. 1. Cibicides sp., 104-642B-13H-4, 74-78 cm $\times 127$. 2. Cibicides sp., 104-642B-13H-4, 74-78 $\mathrm{cm} \times 144$. 3. Cibicides kullenbergi Parker, 104-642B-16H-5, 69-73 cm $\times 85$. 4. Cibicides kullenbergi, 104-642B-16H-5, 69-73 cm $\times 127$. 5. Cibicides kullenbergi, 104-642B-16H-5, 69-73 $\mathrm{cm} \times 187$. 6. Cibicides lobatulus var. grossa, ten Dam and Reinhold, $104-642 \mathrm{~B}-16 \mathrm{H}-5,69-73 \mathrm{~cm} \times 93$. 7. C. lobatulus var. grossa, 104-642B-16H$5,69-73 \mathrm{~cm} \times 93$. 8. C. lobatulus var. grossa, 104-642B-16H-5, 69-73 $\times 144$ (side). 9. Cibicides grimsdalei Nuttall, 104-643A-43X-CC, $\times 127$. 10. Cibicides grimsdalei, 104-643A-43X-CC $\times 144$. 11. Cibicides pseudoungeriana (Cushman), 104-642B-16H-7, 69-73 $\mathrm{cm} \times 255$. 12 . C. pseudoungeriana, 104-642B-16H-7, 69-73 cm $\times 297$ (side). 13. C. pseudoungeriana, 104-642B-16H-7, 69-73 $\times 297$. 14. Praecystammina globigerinaeformis Krasheninnikov, 104-643A-53X-4, 75-78 cm $\times 144$. 15. Trochammina altiformis (Cushman and Renz), 104-643A-47X-CC, 21-25 cm $\times$ 170. 16. Anomalinoides alazanensis (Nuttall), 104-643A-43X-CC $\times 127$. 17. Turrilina alsatica Andreae, 104-643A-43X-CC, 144. 18. Ammosphaeroidina pseudopauciloculata (Mjatliuk), 104-643A-47X-3, 75-79 $\mathrm{cm} \times 102$. 19. A. pseudopauciloculata, 104-643A-47X-CC, $21-25 \mathrm{~cm} \times 187$. 


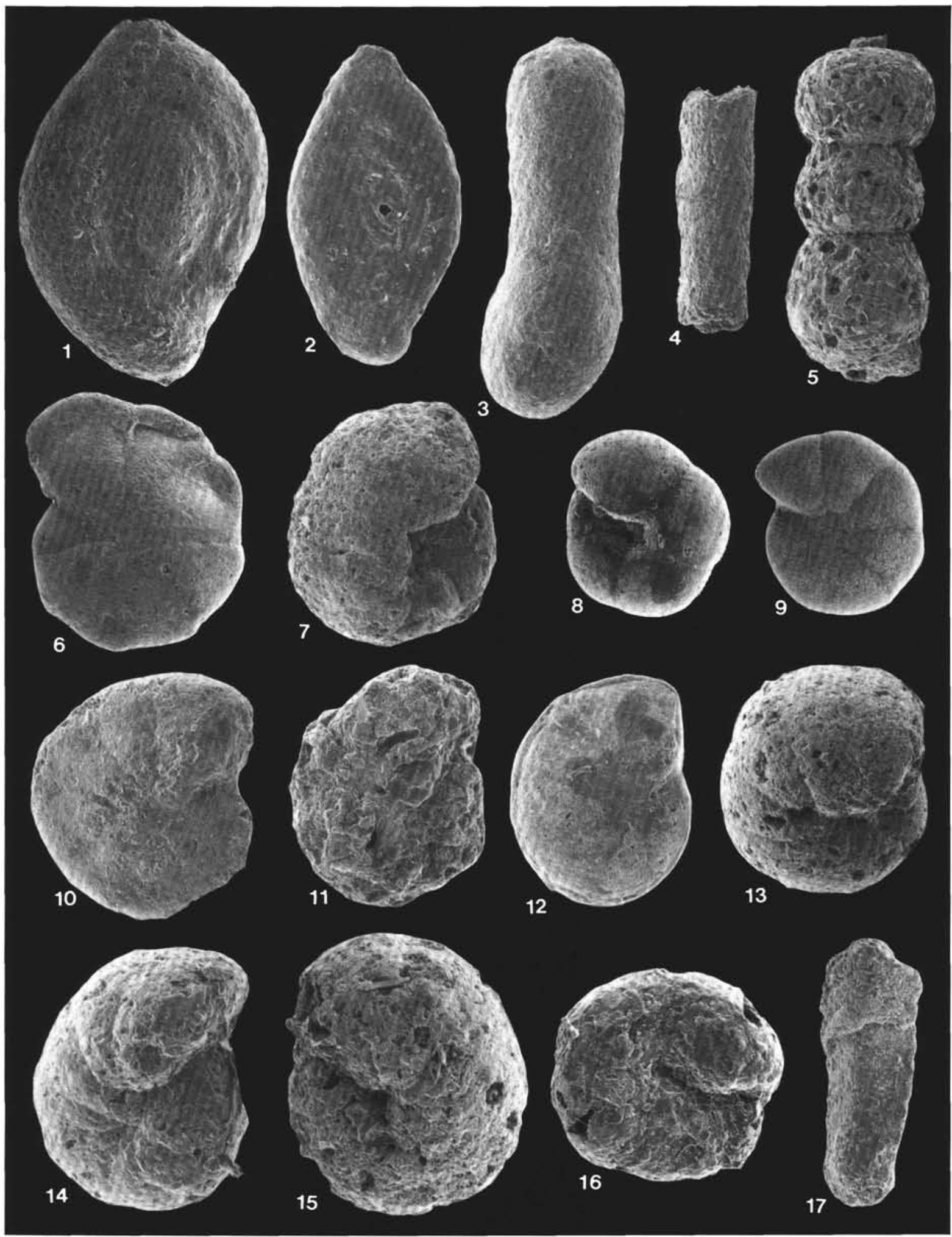

Plate 5. 1. Spirosigmoilinella sp., 104-643A-28X-2, 74-78 $\mathrm{cm} \times 127$. 2. Spiroloccamina sp., 104-643A-14H-CC, $20-24 \mathrm{~cm} \times 170$. 3. Martinottiella communis (d'Orbigny), 104-642B-16H-6, 69-73 cm $\times 93$. 4. Bathysiphon sp., 104-643A-47X-3, 75-79 $\mathrm{cm} \times 68$. 5. Reophax subnodulosus Grzybowski, 104-643A-47X-4, 75-79 cm $\times 51$. 6. Haplophragmoides walteri (Grzybowski), 104-643A-47X-3, 75-79 cm $\times 102$. 7. ? Haplophragmoides sp., 104-643A-47X-3, 75-79 cm $\times 85$. 8. Haplophragmoides kirki Wickenden, 104-643A-53X-4, 74-78 cm $\times 127$. 9. Cyclammina sp., 104$643 \mathrm{~A}-50 \mathrm{X}-\mathrm{CC}, 20-24 \mathrm{~cm} \times 68$. 10. Cyclammina amplectens Grzybowski, 104-643A-36X-5, 80-84 cm $\times 110$. 11. Cyclammina placenta (Reuss), 104-643A-49X-CC, $11-14 \mathrm{~cm} \times 85$. 12. ? Cyclammina cancellata Brady, 104-643A-53X-4, $75-78 \mathrm{~cm} \times 127$. 13. Cyclammina rotundosata (Hantken), 104-643A-47X-3, 75-79 $\times$ 93. 14. Reticulophragmium sp., 104-643A-47X-4, 75-79 cm $\times 127$. 15. Recurvoides deflexiformis (Noth), 104-643A-48X-3, 75-79, $\times 93$. 16. Recurvoides contortus Earland, 104-643A-49X-CC, 11-14 cm $\times 170$. 17. Spiroplectammina spectabilis (Grzybowski), $104-643 \mathrm{~A}-57 \mathrm{X}-\mathrm{CC}, 20-23 \mathrm{~cm} \times 102$. 